\title{
Investor reaction to accounting misstatements under IFRS: Australian evidence
}

\author{
John Goodwin ${ }^{1}$ \\ Professor \\ School of Management \\ Sabanc1 University \\ Istanbul, Turkey \\ Tel: 90-216 4839675 \\ Fax: 90-2164839699 \\ Email: goodwin@sabanciuniv.edu
}

Yigit Atilgan

Associate Professor

School of Management

Sabanc1 University

Istanbul, Turkey

Tel: 90-2164839663

Fax: 90-2164839699

Email: yatilgan@sabanciuniv.edu

Serif Aziz Simsir

Associate Professor

School of Management

Sabancı University

Istanbul, Turkey

Tel: 90-2164839658

Fax: 90-216 4839699

Email: simsir@sabanciuniv.edu

Kamran Ahmed

Professor

La Trobe Business School

La Trobe University

Melbourne, Vic 3086, Australia

Tel: 61394791125

Fax: 61394795971

Email: k.ahmed@latrobe.edu.au

April 2018

Keywords: misstatement news; investor reaction; stealth misstatements

JEL descriptors: M41, M42, M51

\footnotetext{
${ }^{1}$ Corresponding author

We thank the workshop participants at the Budapest Business School, LaTrobe University, the University Tunku Abdul Rahman, Sabancı University, Victoria University of Wellington, the 2016 AFAANZ Conference - Gold Coast, the 2017 EBES conference - Budapest, and the Editor, Deputy Editor and two anonymous reviewers for their comments. We also thank Elnur Aliyev, A. Doruk Gunaydin, Saad Hasan, Jingwen Hu, Maria Naveed, Sumair Saleem and Syed Zaidi for research assistance and The Chinese University of Hong Kong and Sabanc1 University for providing research funding. Any errors are ours alone.
} 
Investor reaction to accounting misstatements under IFRS: Australian evidence

\begin{abstract}
We examine the investor reaction to misstatement news for Australian listed firms from 2006 to 2013 . We find $4.1 \%$ of firm-years have a misstatement and $79 \%$ of misstatements are disclosed initially only in the periodic filings (stealth misstatements). We find no investor reaction for the average misstatement, reactions of between $-2.3 \%$ and $-2.8 \%$ ($1.5 \%$ and $-1.7 \%$ ) for misstatements that reduce prior-period earnings or equity (affect revenue), and reactions of between $-1.3 \%$ and $-2.7 \%$ for non-stealth misstatements. Investor reactions are more negative for non-stealth misstatements that reduce priorperiod earnings or equity than to stealth misstatements.
\end{abstract}




\section{Introduction}

In recent years, research on the causes and economic consequences of misstatements of financial reports has assumed significant importance, evidenced by more than 150 studies undertaken in the U.S. (Karpoff et al., 2017). News of a misstatement signals that an issued financial report was unreliable. The economic consequences of misstatements are often costly for the firms and their investors, resulting in negative investor reactions at the announcement date and thereafter (Anderson and Yohn, 2002; Files et al., $2014)^{2}$. While there are many U.S. studies, international research on misstatements is rare. In a review of academic research on misstatements, Sellars (2013) notes that most studies use U.S. data, and he calls for extending this research to an international context to understand the causes of and reactions to misstatements in other countries. A broader view is required because firms have become more global and regulators are working to harmonize accounting practices across the world (Sellars, 2013, p.13). In the meantime, the Australian Securities and Investments Commission (ASIC) expressed concern about the financial reporting quality of Australian firms. Beginning from July 1 2014, the ASIC reintroduced a policy that requires firms to make public announcements when they make material changes to information previously provided to the market to improve "...the level of market transparency" (ACCI media release 2016-205MR) ${ }^{3}$. In response to the 2015 audit inspection review, the ASIC found that auditors did not get reasonable assurance that the accounts were free of material misstatement in $19 \%$ of audit areas. We examine for the first time, the investor reaction to misstatement news for Australian listed firms, and in so doing, provide new information on the quality of Australian financial reporting.

Shared institutional features in the common-law-based corporate-regulatory systems in Australia and the U.S. suggests that investor reactions to new accounting information could be similar for the two countries. However, other reasons suggest that the reactions might not be similar. First, unlike in the U.S. (where a firm must lodge a Form 8-K within four days of determining that prior accounts cannot be relied upon), there is no specific requirement in Australia to disclose the intention to restate accounts.

\footnotetext{
${ }^{2}$ Anderson and Yohn (2002) identified other negative consequences including increased cost of capital, litigation, and regulatory enforcements, as well as auditor resignations, executive turnover, reduced investor confidence.

3 This media release is available at: http://asic.gov.au/about-asic/media-centre/find-a-media-release/2016releases/16-205mr-asic-review-of-31-december-2015-financial-reports/
} 
Australian firms decide to announce separately misstatement news to the market considering the continuous disclosure provisions of the Australian Securities Exchange (ASX) and the Corporations Act 2001. Our data show that Australian firms are usually not forthcoming in this regard. Second, the Australian stock market has a much lower level of institutional ownership than the U.S. (Fereira and Matos, 2008) and it is comprised of smaller firms with fewer analysts following them. Third, the litigation risk in Australia is lower than in the U.S. (Morabito, 2010) and the probability of being sued accounts for approximately half of the investor reaction to misstatement announcements in the U.S. (Bardos et al., 2013). These types of reasons could have prompted Sellars (2013) to call for research using non-U.S. data. How investors react to Australian misstatement news is an important and unexplored empirical question.

Recently, Karpoff et al. (2017) expressed concern about the extent of investor reactions reported in prior studies because commercially available databases fail to capture important news dates and events for some misstatement cases $^{4}$. Karpoff $e t$ al. (2017) argue that U.S. studies using the AAER, GAO, Audit Analytics and SCAC databases underestimated the stock market's reaction to misstatement news and they estimate that the mean one-day investor reaction using their hand-collected data is more than double the reaction using the dates from these databases. ${ }^{5}$ Our sample construction method, detailed in Appendix 1, seeks to capture unbiasedly the investor reactions to misstatement news, and provide the most accurate measure possible of the wealth effects of misstatements.

From 2006 to 2013, we find a total of 704 firm-years with a misstatement, corresponding to $4.1 \%$ of all listed firm-years. The percentage of misstatements that change prior-period earnings or equity is about 60 , and the median of the percentage corrections to earnings (equity) is $-4.9 \%(-1.3 \%)$. Due to outliers, means are also negative and much larger than the medians. More than $78 \%$ of misstatements are disclosed only in the periodic filings, that is, the half-year and annual reports. In the year a firm made

\footnotetext{
${ }^{4}$ Karpoff et al. (2017) highlight four areas of concerns. First, the initial public revelations of financial misconduct occur months before the initial coverage in these databases. Second, these databases collect just one type of event, so they omit other relevant announcements that affect a researcher's use of the events. Third, most of the events captured by these databases are unrelated to financial fraud. Fourth, the databases miss large numbers of events that they were designed to capture.

${ }^{5}$ Using only data from the databases results in underestimates of the mean investor reaction by between $56 \%$ and $73 \%$ (Karpoff et al., 2017). The underestimates using median returns are larger for each of the databases.
} 
an accounting error leading to the misstatement, it was younger, more likely to be audited by a non-Big 4 audit firm or by a small audit office, to have an unclean audit opinion, to be in a technology industry and less likely to be in an extractive industry, compared to other firms. Univariate tests show stock price reactions of $-1.5 \%(-2.3 \%$ and $-2.5 \%)$ for misstatements that change (reduce) prior-period earnings or equity. We also document price reactions between $-5.4 \%$ and $-5.8 \%$ for misstatements attributable to fraud, and between $-1.3 \%$ and $-2.7 \%$ for non-stealth misstatements, consistent with U.S. studies (Files et al., 2009; Scholz, 2013; Adams et al., 2015). Multivariate tests show negative (positive) reactions for misstatements that reduce earnings or equity and those that affect revenue (stealth misstatements) with similar magnitudes to the results obtained from univariate tests. Negative reactions to misstatement corrections that reduce earnings or equity are larger for non-stealth disclosures than for stealth ones, consistent with U.S. studies (Files et al., 2009 and Myers et al., 2013). However, we find no such relations for revenue or core expense corrections. Overall, investor reaction to Australian misstatement news is weaker than in the U.S. but stronger than in China, where a very weak reaction has been reported (Wang and $\mathrm{Wu}, 2011$ ). Additional tests suggest that the disclosure of more serious misstatement corrections on the same date as the announcement of earnings could contribute to the weaker results. When significant, our results are broadly consistent with U.S. studies, suggesting that investors regard some Australian misstatement news as valuable.

This paper makes three contributions to the misstatements literature. First, we show that in Australia, the investor reaction to misstatement news is weak and negative both for revenue corrections and for corrections that reduce earnings or equity. These results are consistent with a lower-litigation environment, less salient misstatement disclosure rules and lower institutional ownership than in the U.S. where reactions are generally stronger. They are also consistent with a stronger financial reporting regime than in China where reactions are weaker. We show that the negative investor reactions for corrections that reduce earnings or equity are larger for disclosures that are more salient. We also show that disclosure of large negative corrections to earnings and corrections to core expenses and revenues are more likely to be on an earnings announcement date, than other corrections. These findings suggest that if disclosure of misstatements is more salient the market could be better informed. Second, we 
provide evidence that appears inconsistent with the proper functioning of the continuous disclosure rules because the proportion of salient disclosures of prior-period errors is only $21 \%$, which seems low for such an important corporate event. Finally, we show that accounting misstatements are a good proxy for financial reporting quality in Australia because misstatement errors are associated with established measures of accounting quality proxies in the expected directions. By documenting misstatement incidence using a comprehensive and rigorous data collection method, we are informing the ASIC of the extent of this type of financial reporting quality in Australia.

In the next section, we develop hypotheses for the relations between types of misstatement news and stock returns. Section 3 describes the sample data and descriptive statistics followed by coverage of the research methodology. Empirical results from univariate and multivariate tests are presented in Section 4. Section 5 concludes.

\section{Australian GAAP for Misstatements, Literature Review and Hypotheses}

\subsection{Australian GAAP for Misstatements}

Since the introduction of IFRS, a material, prior-period error should be recognized in the comparatives or the opening balances of assets, liabilities or equity for the prior period, if practicable. ${ }^{6}$ An accounting standard amendment from 2009 requires firms to disclose a balance sheet at the beginning of the earliest comparative period when it makes a prior-period adjustment (AASB 101, para 10f). In contrast, U.S. GAAP requires all prior periods to be restated. Due to the absence of the "if practicable" condition from U.S. GAAP, misstatement severity is measured more accurately using U.S. data because Australian firms can use the impracticality argument to avoid disclosure of the effects of the error(s) on prior years. Consistent with this contention, the mean number of years restated is 1.1 in our sample (see Table 2, Panel C), compared to 1.7 in the U.S. (see Scholz, 2013, Table 4, p.12).

Under Australian GAAP, the nature of the error, the line items affected by the correction of the error, the amount of the correction at the start of the earliest period corrected and the change to earnings per share must be disclosed (AASB 108, para 49). As noted, Australia has no other specific disclosure

\footnotetext{
${ }^{6}$ AASB 1004 Accounting Policies, Changes in Accounting Estimates and Errors paragraph 42 - 45.
} 
requirement for misstatements. Instead, the requirement to disclose a misstatement can be caught by the Australian Stock Exchange (ASX) Listing Rule 3.1 (continuous disclosure rule): "Once an entity is or becomes aware of any information concerning it that a reasonable person would expect to have a material effect on the price or value of the entity's securities, the entity must immediately tell ASX that information." ${ }^{77}$ In contrast, in the U.S., Final Rule: Additional Form 8-K Disclosure Requirements and Acceleration of Filing Date requires a firm to lodge a Form 8-K within four days of determining that prior accounts cannot be relied upon. ${ }^{8}$

\subsection{Literature Review}

Almost all studies examining investor reactions to misstatement news use U.S. data (Sellars, 2013) and they find negative reactions. ${ }^{9}$ Anderson and Yohn (2002) report returns of $-3.8 \%$ around misstatement news, and the most significant negative reaction is for misstatements attributable to fraud $(-12.8 \%)$ followed by revenue-recognition issues (-7.9\%). Owers et al. (2002) examine nine categories of misstatements and find that the most negative investor reactions are attributable to accounting issues such as errors and irregularities. Palmrose et al. (2004) report an investor reaction to misstatement announcements of $-9 \%$ and that more negative abnormal returns are associated with more negative misstatements that involve fraud, that decrease earnings and for which the misstatement is not quantified. Hribar and Jenkins (2004) also report an announcement of cumulative abnormal returns (CARs) of $-9 \%$ and conclude that misstatements reduce perceived earnings quality and increase the cost of capital. Agrawal and Chandha (2005) report returns of $-4.2 \%$ for their full sample and find that core earnings corrections generate returns that are $4 \%$ more negative than non-core earnings corrections. Desai et al. (2006) report CARs of $-11.1 \%$ and state that revenue corrections generate the largest negative reaction, followed by corrections for improper cost recognition.

Recent U.S. studies report less negative CARs perhaps because there are fewer misstatements of revenue and core expenses in recent years (Scholz, 2013). Scholz (2013) reports that over the decade from 2003

\footnotetext{
${ }^{7}$ Section 674 of the Corporations Act makes Listing Rule 3.1 legally binding for listed firms.

${ }^{8}$ Available at https://www.sec.gov/rules/final/33-8400.htm.

${ }^{9}$ Studies using long return windows spanning several months also document market value declines associated with misstatements. See for example, Kinney and McDaniel (1989) and Wallace (2000) for U.S. evidence and Ahmed and Goodwin (2007) for Australian evidence.
} 
to 2012 , the average stock price reaction to misstatements in the U.S. is $-1.5 \%$ (median of $-0.01 \%$ ), but she still finds more negative reactions to misstatements involving fraud, revenue and negative earnings corrections. For the period from 2002 to 2008, Files et al. (2014) find CARs of between $-1.3 \%$ and $1.6 \%$ for repeat misstatements. For the 12-year period prior to 2011, Adams et al. (2015) report CARs of $-0.6 \%$ for U.S. real estate investment trusts of and $-1.6 \%$ for non-REITs around misstatement announcements. To the best of our knowledge, Wang and Wu (2011) is the only non-U.S. study that examines investor reaction to misstatement news. They examine China, a country with similar accounting for misstatements to Australia. They find very weak evidence of a negative reaction and they attribute their results to the inefficiencies of the Chinese market mechanisms (e.g., low-litigation environment and low demand for high-quality auditors), misstatement behaviours of Chinese firms and lower reliance of Chinese investors on accounting data.

Recent U.S. also studies examine the differential investor reaction to various types of salience of misstatement disclosure (Files et al. 2009; Myers et al. 2013; Scholz 2013). ${ }^{10}$ Theory differs as to whether disclosure salience should affect investor reactions. According to the efficient markets hypothesis (EMH), stock prices respond promptly and fully to all publicly available information (Fama, 1970), and it should not matter if misstatement news is disclosed prominently in a press release or less prominently in the notes to the financial statements for example. The EMH ignores investors' abilities to process information, and it assumes that the average investor is rational. The limited attention theory (LAT) argues that when humans devote attention to a particular task, the attention we can devote to other tasks is reduced because of limits in our ability to process information and perform multiple tasks simultaneously (Kahneman, 1973). LAT predicts that the average investor will not process a piece of information as efficiently when it is released at the same time as other information than when that piece of information is released at another time. Files et al. (2009) examine disclosure salience when managers exercise considerable discretion over how they announce an accounting misstatement in a press release. Some firms issue a press release that discloses the misstatement in the headline (high salience). Others

\footnotetext{
${ }^{10}$ Misstatements not only negatively affect shareholder wealth of the restating firms but also adversely affect the wealth of non-restating firms within the same industry (Gleason et al., 2008).
} 
provide a press release with a headline on a different subject but describe the misstatement in the body of the release (medium salience). The remaining firms discuss the misstatement at the end of the press release in a footnote to operating results (low salience). They find that three-day returns differ substantially across the three categories of disclosure salience, averaging $-8.3 \%,-4.0 \%$, and $-1.5 \%$ for high, medium, and low salience, respectively. Files et al. (2009) use the LAT to explain their findings, arguing that managers in high-salience firms either seek to lower the firm's cost of capital or are naïve to the stock price consequence of their disclosures. Myers et al. (2013) find a similar result to Files et al. (2009) by examining all misstatements disclosures rather than only press releases. Myers et al. (2013) report that $22 \%$ of U.S. firms in their sample disclose the misstatements only in the notes to the accounts and the announcement CARs of these firms are 1.6\% higher (less negative) than those firms that highlight the misstatement via a press release. Scholz (2013) also finds that misstatements disclosed more saliently are associated with more negative investor reactions.

\subsection{Hypotheses}

Investors revise their expectations of a U.S. firm's present value of future net cash flows downward when it announces a misstatement. The changes in their beliefs presumably occur because misstatements increase uncertainty about the quality of a firm's internal control system or its management (Hribar and Jenkins, 2004), signal lower future earnings levels or earnings quality (Anderson and Yohn, 2002; Palmrose and Scholz, 2004) or indicate that the firm faces a higher litigation risk in the future (Bardos et al., 2013). Australia is a market-oriented country with a legal system based in common law, strong institutions and a diverse shareholder base similar to the U.S. Thus, financial reporting quality should be higher than in countries such as China, where accounting quality is lower (Ball et al., 2003; Fan and

Wong, 2002; Wang and Wu, 2011). Consequently, one expects timely releases of misstatement news by Australian firms and prompt processing of them by Australian market participants. In Australia, news of an error in audited financial reports should surprise market participants and investor reactions to that news should be closer to those in the U.S. rather than to those in China, where reactions are negligible (Wang and $\mathrm{Wu}, 2011$ ). 
However, differences in accounting disclosure rules, stock market composition and characteristics, levels of litigiousness and nature of the misstatement errors between Australia and the U.S. could attenuate investor reactions to Australian misstatement news. Approximately 79\% of Australian firms (see Table 2, Panel B) disclose misstatement news only in their periodic filings. In contrast, this rate is $22 \%$ in the U.S. in recent years (Myers et al., 2013). Prior studies report that the investor reaction to misstatement news disclosed only in periodic filings is weaker than when the news is disclosed separately. Furthermore, in Australia, to avoid the requirement to restate several prior years, firms can argue that it would be impracticable to restate prior-period accounts, an option not available to U.S. firms. This suggests that misstatement details such as trends in earnings are made clearer under U.S. GAAP. Table 2, Panel C shows that the mean number of corrected years is 1.1, whereas the analogous figure is 1.7 in the U.S. (Scholz, 2013), which is consistent with Australian firms relying on the impracticable "get-out" clause. This impracticability clause also applies to China (Wang and Wu, 2011). Lower-quality misstatement disclosures could increase uncertainty among investors, resulting in more mixed reactions among them. For these reasons, one expects a weaker investor reaction to misstatement news in Australia than in the U.S.

There are important differences in stock markets' abilities to impound information across developed economies. For instance, Griffin et al. (2011) find large differences in investors' response to news announcements across developed countries, primarily caused by differences in insider trading and information dissemination in those countries. The extent to which stock prices impound information is positively related to the level of institutional ownership. This result is observed not only in the U.S. but also in Japan (Luo et al., 2014) and Australia (Gallagher et al., 2013). Since Australia's stock market composition differs markedly from that of the U.S. with respect to levels of institutional ownership (Fereira and Matos, 2008) and average firm size, the average level of information dissemination (insider trading) could be lower (higher) in Australia. Furthermore, Australia has a much smaller market than the U.S. with fewer actors such as analysts participating in trading, and 'hidden' information may take longer for the market to discover. For these reasons, weaker reactions to misstatement news can be expected for Australia. Finally, despite an increase in shareholder class action lawsuits in Australia in 
recent years (Legg, 2008), this increase has been modest and Australia remains a lower-litigation environment than the U.S. (Morabito, 2010; Murphy, 2013). Approximately half of the magnitude of the investor reaction to U.S. misstatements is explained by litigation risk (Bardos et al., 2013). Thus, weaker investor reactions than in the U.S. can be expected to the extent that the results of Bardos et al. (2013) also apply in Australia.

With respect to the types of accounting issues associated with misstatements, Australia has a much higher proportion of note-disclosures than the U.S. Note-disclosures make up $21 \%$ of our sample (see FNOTEDIR in Table 2, Panel A) whereas Scholz (2013) reports about 3\% for the U.S. over a similar period. Common among these notes are corrections in the directors' remuneration note, which we do not expect to impact investors' expectations of the firm's earnings. Misclassifications in the cash-flow statement, income statement and balance sheet have little effect on future earnings, and these issues comprise approximately $26 \%$ of all misstatements (see CFMISS, ISMISSEPS, DEQMISS and ASSETMISS in Table 2, Panel A). There are about $21 \%$ of these types of misclassifications in the U.S. according to Scholz (2013). About 33\% (17\%) of Australian misstatements negatively (positively) affect prior-period earnings and the median change to those earnings is about $-14 \%$ (14\%) (untabulated). Scholz (2013) reports that about 53\% (14\%) of misstatements negatively (positively) affect prior-period U.S. firms' earnings and the median change in earnings is about $-15 \%(14 \%)$. The percentage of negative earnings corrections is much lower in Australia than in the U.S., suggesting a weaker investor reaction in Australia. Differences in the types of accounting issues also suggest a weaker investor reaction in Australia than in the U.S. We are unable to make a directional prediction for the average misstatement, so our first hypothesis is:

H1: There is no relation between misstatement news and abnormal stock returns.

Our next set of hypotheses concerns differential investor reactions to partitions of misstatement corrections. Since the average misstatement seems to cause downward revisions in the firm's future earnings (Hribar and Jenkins, 2004), one expects some accounting issues associated with misstatements to be weaker signals for the firm's future earnings. The market could view corrections to recognised numbers positively or negatively, depending on whether earnings or equity is increased or decreased. 
Thus, our first partition is for misstatement corrections that change earnings or equity and other corrections and the hypothesis is in the null form:

H2A: There is no difference between the CARs of misstatement corrections that change priorperiod earnings or equity and other misstatement corrections.

One expects investors to regard downward earnings corrections more negatively than upward ones. We expect a differential reaction in Australia because accounting quality is high, unlike in China (Wang and $\mathrm{Wu}, 2011)$. However, as in China, Australian firms are not required to restate earnings before the start of the comparative year if that is impracticable. Following Wang and $\mathrm{Wu}$ (2011), to ensure that we capture all prior-period earnings corrections, we also examine equity corrections. Moreover, to ensure that the directional effect of the correction is unambiguous, in this analysis, we exclude cases where either earnings or equity takes the opposite sign. For example, we exclude a correction that reduces (increases) prior-period earnings and increases (reduces) prior-period equity from this analysis.

H2B: Misstatement corrections that reduce prior-period earnings or equity have lower CARs than misstatement corrections that increase prior-period earnings or equity.

Investors react more strongly to permanent income components than to one-time items (Elliott and Hanna, 1996). Prior U.S. research finds that negative earnings corrections and those affecting revenue and core earnings have lower CARs than other recognized misstatements (Anderson and Yohn, 2002; Palmrose et al., 2004; Scholz, 2008, 2013). Since corrections to revenue and core expenses can be upward or downward and since Australia has important differences in its litigation level, institutional ownership and size composition that could diminish the impact of misstatements, our next hypothesis is in the null form:

$\mathrm{H} 2 \mathrm{C}$ : There is no difference between the CARs for misstatement corrections that change revenue or core expenses and other misstatement corrections.

Our final hypothesis concerns the level of salience of misstatement disclosure. The theory of investors' limited attention (Hirschleifer and Teoh, 2003) predicts a positive relation between the disclosure saliency of misstatement disclosures and the absolute magnitude of the investor reaction to their 
announcements. As noted, most Australian misstatements are only disclosed in the firms' periodic filings. Files et al. (2009) and Scholz (2013) find that non-stealth misstatements have more negative CARs than stealth misstatements in the U.S. Conversely, if markets are efficient, there should be no difference in the investor reaction for stealth and non-stealth disclosures. Since we have no directional expectation, our third hypothesis is as follows:

H3: There is no difference in investor reaction to stealth misstatements versus non-stealth misstatements.

\section{Empirical Tests}

\subsection{Sample selection}

A misstatement is defined as a "difference between the amount, classification, presentation, or disclosure of a reported financial report item and the amount, classification, presentation, or disclosure that is required for the item to be in accordance with the applicable financial reporting framework. Misstatements can arise from error or fraud." (ASA200, para 13.4(i)). In the interest of consistency with Australian auditing standards, we use this definition to identify a misstatement for inclusion in our dataset. Prior U.S. studies report negative investor reactions to misstatement news (Palmrose et al., 2004; Adams et al., 2015) and differential investor reactions to misstatement characteristics, such as whether a correction affects core or non-core earnings (Palmrose et al., 2004; Scholz, 2013). Due to the absence of an Australian classification of misstatement data and for comparability, we follow key U.S. studies for our classification scheme of misstatement issues in our tests.

We hand-collect our data from all publicly available potential sources of misstatements, namely, the websites of the Australian Stock Exchange (ASX), the Australian Securities and Investments Commission (ASIC), and the Australian Financial Review. Additionally, we complement our data collection using a Factiva search. Appendix 1 shows the details of the sample-collection method. Our final sample comprises 704 firm-years (540 different firms) for the period 2006-2013, within which 415 firms had one misstatement, 97 had two, 18 had three, 9 had four and 1 had five (untabulated). ${ }^{11}$ Our

\footnotetext{
${ }^{11}$ In our sample, the percentage of firms that are repeat misstaters is 23 , which is lower than the $38 \%$ reported in Files et al. (2009) for their sample of U.S. firms for the 7-year period prior to 2008.
} 
sample percentage, which is $4.1 \%$ of all listed firm-years, is quite close to the $4 \%$ reported by ASIC for the period from 2010 to 2015 (16-205MR ASIC review of 31 December 2015 financial reports).

\section{Table 1 about here}

Table 1 shows the descriptive statistics. Panel A shows that the number of misstatements increased monotonically from 63 in 2006 to 122 in 2009 and then decreased monotonically thereafter to 65 in 2013. Increases in the number of listed firms do not explain this trend because the percentages of listed firms with misstatements also increased monotonically from 3.8 in 2006 to 6.3 in 2009 . Although it is outside the scope of this paper to explain these trends, the 2007 uptick could be due to the identification of GAAP differences by scrutinizing prior-period accounting practices around the initial use of IFRS. The continued upticks through 2009 could be due to the impending introduction of the amendments to the accounting standard, AASB101. More specifically, for fiscal years beginning 1 January 2009, the new AASB101 requires a third balance sheet for the earliest restated period to be prepared, seemingly causing some firms to re-evaluate their accounting policies. To avoid this costly requirement, a firm can restate on June 30,2009. Changes in the state of the economy may also explain the trends, especially for the years leading to the global financial crisis. ${ }^{12}$ There are 607 (546) error years from 2006 to 2013 (2006 to 2011) or 4.1\% (4.9\%) of firm fiscal years. The Error Years variable's statistics are understated the most for the 2013 year, because that is the most recent year for which we collected data and the mean reporting lag is 1.2 years (see Table 2, Panel C). ${ }^{13}$ We show the earliest error year in the two columns at the far right of Panel A of Table 1, that is, only one error year for each misstatement year. In our examination of misstating firms' characteristics set forth below, we use the earliest error year to identify the firms because 70 of the sample firms have more than one error year for a misstatement year. In that examination, we use only the data through 2011 to ensure that the majority of errors are within the period used for our analyses, following prior studies (Francis et al. 2013). Panel B of Table 1 shows

\footnotetext{
${ }^{12}$ We thank an anonymous reviewer for this suggestion. Xu et al. (2011) find similar upward trends in going concern reporting.

${ }^{13}$ We do not tabulate error years before 2006 because Australian GAAP was different then and we have not gathered data for all prior error years indicating that the error year numbers will be understated. The error year frequencies prior to 2006 are in parentheses: 2005 (65), 2004 (25), 2003 (3), 2002 (4), 2001 (3) and 1998 (1).
} 
the percentage of misstating firms by industry. ${ }^{14}$ The percentages are generally in line with the overall industry percentages, except for the Basic Resources industry, which is under-represented in our sample compared to its weight in the Australian market, and the Industrial Goods \& Services, Retail, Technology industries, which are overrepresented in our sample compared to their weights in the Australian market.

Table 2 Panel A shows frequencies of the accounting issues underlying misstatements. In the absence of an Australian classification scheme, we use Scholz's (2013) scheme for U.S. firms, modified for Australian GAAP. The accounting issues' variable names and definitions appear in Appendix 2. We include corrections for misstatements of upward noncurrent asset revaluations (17 observations) in the INVESTING category. U.S. GAAP does not allow these revaluations. As in Scholz (2013), the percentages of misstatements do not total 100 because a misstatement case can have more than one accounting issue. The most common accounting issue involves corrections to footnotes (including segment notes) or Directors' Reports (denoted FNOTEDIR), at 20.6\% of total misstatements. In contrast, Scholz (2013) reports a percentage of 3\% for footnote-disclosure issues. Much of this difference in percentages is likely attributable to our inclusion of corrections to the Directors' Report (which became more common after 2008) within our dataset. The second most-common issue is tax-related corrections $(T A X)$ at $15.3 \%$, followed by revenue-recognition corrections (REV) at $13.1 \%$.

Table 2, Panel B shows that the initial disclosure of the error occurs within the half-year and financialyear report filings for 625 (89\%) misstatement years, but only 70 of them are accompanied by a separate announcement highlighting the misstatement, such as a press release or an ASX announcement. Thus, for 555 of our misstatement years, or $79 \%$ of our sample, misstatement errors are disclosed initially within the periodic filings. We use the term 'stealth misstatement' to describe such errors. Untabulated statistics show that there are $356(85 \%)$ corrections that change earnings or equity that are stealth misstatements, whereas there are $199(70 \%)$ corrections that do not change earnings or equity that are stealth misstatements. The difference is statistically significant, with a Chi-square statistic equal to 23.8

\footnotetext{
14 We use Datastream industry classifications.
} 
$(p<0.01)$. Since corrections that change recognized information are regarded as more severe than corrections that do not change recognized information (Anderson and Yohn, 2002; Palmrose et al., 2004), this evidence is consistent with less disclosure saliency for more severe misstatements, and supports the ASIC's recent concerns about financial reporting quality.

\section{Table 2 about here}

Panel $\mathrm{C}$ of Table 2 shows descriptive statistics of the misstatement variables. MISSTATEMENTLAG is the number of years from the misstatement year to the earliest year of an error. We find that the earliest error year is 1.2 years before the misstatement year, on average. The maximum statistic shows that the earliest error year is at most seven years before a firm's misstatement year. Similar to Hirschey et al. (2015), we measure disclosure timeliness (Error lag) by the number of days from the lodging of the most recent incorrect audited financial report to the earliest date of disclosing the error. Error Lag is equal to one day when an ASX announcement about the error occurs on the same day as the lodgement of the incorrect financial report. The table shows that the mean (median) of the error lag is approximately 228 (239) days and the $20^{\text {th }}$ percentile is 120 days (untabulated), indicating that misstatement disclosures are not timely for most firms. In contrast, Hirschey et al. (2015) report a mean (median) of 175 (139) days for a sample of U.S. firms. As noted, the U.S. requires disclosure within four days of the error identification, which could explain these differences in disclosure timeliness. The large maximum error lag of 1,789 days is a case where a financially distressed firm restated its accounts after a long period without lodging any accounts. Most firms restate only one year, indicated by the mean (median) of 1.1 (1) for the Number years restated variable. The mean of 1.6 for the Number accounting issues variable is lower than the mean of 2.2 reported in Scholz (2013), probably due to the larger proportion of disclosure-only misstatements in our sample, namely, the FNOTEDIR variable as shown in Panel A. The mean of 0.6 for Earnings or Equity change variable indicates that the percentage of misstatements that increase or decrease earnings or equity is $60(\mathrm{~N}=418 \text {, untabulated })^{15}$. Some corrections change only earnings or only equity. This occurs most commonly because of errors that affect only earnings earlier than the prior year and the firms not disclosing the effect on earnings for those periods but instead

\footnotetext{
${ }^{15}$ References to earnings or equity are to consolidated net income or consolidated equity in this paper.
} 
disclosing the effect on equity. There are also share-based payment accounting errors, whose correction changes earnings but not equity. The mean (median) percentage change to earnings is $-39.2 \%(-4.9 \%)$ and for equity, it is $-8.3 \%(-1.3 \%)$. These values indicate the presence of some very large percentage decreases for earnıngs and equity. The maximum percentage decrease for earnings of 4,719.8 occurred for the correction of an asset-impairment error for a disposal group held for resale, changing a firm's loss from $\$ 5.77$ million to $\$ 278.33$ million. The maximum percentage decrease for equity of 469.3 occurred for the correction of a consolidation error, changing a sample firm's equity from $\$ 0.71$ million to $-\$ 2.62$ million. ${ }^{16}$ Other untabulated data show that $83 \%$ of firms do not disclose the initiator of the misstatement and of the remainder, $11 \%$ of misstatements are by management, $4 \%$ are by the ASIC and $2 \%$ are by auditors. The number of misstatement years associated with fraud is $21(2 \%)$. We exclude a variable measuring the initiator of the misstatement from our models because of significant data error in its measurement. To avoid a look-ahead bias in our analyses, we code a disclosure as "fraud" when the words "fraud" or "irregularity" appear in the disclosure.

\section{Table 3 about here}

Prior to undertaking investor reaction tests, it is important to examine the suitability of Australian misstatement data as a financial reporting quality proxy for two reasons. First, one expects the investor reaction to be weak if misstatements are a poor indicator of financial reporting quality (Wang and $\mathrm{Wu}$, 2011). Second, differences in misstating firms' characteristics between Australia and other countries could explain differences in investor reactions between them. Firm size is a risk proxy (Fama and French, 1993), and there is an inverse relation between firm size and the strength (Freeman, 1987) and variability (Atiase, 1985) of the market's reaction to news. We perform univariate comparisons of means and distributions and estimate logit models explaining misstatement events based on prior research. We use the earliest year of the error to identify misstatement firms, and we eliminate misstating firms' data from any other of their error years and from the sample of control firms for valid comparisons. Otherwise, we use all ASX-listed firms in our control sample. The mean of the misstatement lag is 1.2 years (see Table 2, Panel C), thus, in these analyses, we use 2011 as our final year to allow enough time

\footnotetext{
${ }^{16}$ The companies are Australasian Resources Limited and Ausmani Limited, respectively.
} 
after the initial error year for most errors to be disclosed in our sample period. Panel A of Table 3 shows means and medians of misstatement and control firm-years for various firm characteristics. Variable definitions appear in Appendix 3. In addition, the statistics in Table 1 suggest dummy variables for the IFRS year and the year thereafter, namely, 2006 and 2007, ${ }^{17}$ and for Basic Resources (MINE) and Technology and Telecommunications $(T E C H)$ industries.

Univariate test results are shown in Panel A of Table 3. Firm size (SIZE) and profitability (ROA, LOSS) variables show that firms that subsequently have a misstatement are larger and more profitable in their earliest error year. They also have higher leverage, pay higher audit fees and are clients of smaller audit offices. Moreover, they are more likely to be in a technology industry and have misstated in 2006 or 2007 (IFRS). Furthermore, they are less likely to be audited by a Big 4 audit firm or be in the extractive industries (MINE). To examine the relationships between firm characteristics and the incidence of errors subsequently corrected more formally, we estimate the following logistic regression:

$$
\text { ERRORYEAR }=\alpha+\gamma X^{F}+\delta X^{O}+\kappa_{j}+\lambda_{t}+\varepsilon
$$

where ERRORYEAR equals unity if the firm had an error that fiscal year which was subsequently corrected and zero otherwise. $X^{F}$ are the firm-specific attribute variables and $X^{O}$ are other attribute variables that may affect ERRORYEAR. Appendix 3 provides these variables' definitions, the signs of their expected coefficients and references to supporting literature. We estimate model (1) with and without firm-fixed effects to control for firm-specific variables that are stable over time such as governance mechanisms. The model without firm fixed effects is denoted by Model 1A and the model with firm fixed effects is denoted by Model 1B. The industry group and year group indicator variables, denoted by $\kappa_{j}$ and $\lambda_{t}$, respectively, are included to control for industry and time effects on estimated ERRORYEAR. Throughout this paper, regression standard errors are clustered by firm and year following Gow et al. (2010), and two-tailed $p$-values are presented. Regression results are shown in Panel B of Table 3. We find consistent evidence across both models that misstatement firms are less likely to be audited by a Big 4 audit firm and more likely to receive an unclean audit opinion, to be

\footnotetext{
${ }^{17}$ The first fiscal year of IFRS was 2005 only for firms with a 31 December fiscal year end, which is approximately $10 \%$ of listed firms.
} 
younger and to be audited by a smaller audit office, consistent with prior studies. We also find that misstatement firms are more likely to be in the Telecommunications or Technology $(T E C H)$ industry. These results suggest that misstatement data are a good indicator of financial reporting quality in Australia because clients of Big 4 audit firms and large audit offices have higher financial reporting quality (DeFond and Zhang 2014, Francis and Yu 2009). Moreover, younger firms and those with unclean audit opinions are more likely to have weaker internal control systems (Doyle et al., 2007). Furthermore, firms in technology industries have more complex accounting (Francis and Gunn, 2015). We also find that $L E V, L A F, N E W$ and IFRS load positively in the cross-sectional model. We do find some inconsistent evidence: the SIZE coefficient is positive and significant, but only in the fixed-effects model, and the $R O A$ coefficient is positive and significant, but only in the cross-sectional model. Since Australian GAAP permits firms to avoid disclosing the effects of errors on reporting periods earlier than the prior period for reasons of "impracticability", measurement error in the earliest year variable is an unavoidable problem. To reduce this error, we examine the notes about the misstatements and remove the cases in which the firms disclose that it is impracticable to restate earlier years. We are certain of the error year for 437 cases. Untabulated results give the same inferences. ${ }^{18}$ One concludes that Australian misstatement data are a solid indicator of financial reporting quality for that country.

\subsection{Measurement of variables}

We employ a one-factor event study model to estimate firms' abnormal returns around misstatement announcements. First, for each firm, we estimate market model parameters by running an ordinary least squares regression in the estimation period.

$$
R_{i, t}=\alpha_{i}+\beta_{i} R_{m, t}+\varepsilon_{i, t}
$$

where $R_{i, t}$ is the return to firm $\mathrm{i}$ at day $\mathrm{t}, R_{m, t}$ is the return to the market portfolio at day $\mathrm{t}$, and $\varepsilon_{i, t}$ is the zero-mean constant variance error term. We set the estimation period as $(-126,-6)$ trading days relative

\footnotetext{
${ }^{18}$ In other untabulated tests, we estimated model 1A including 12-month abnormal stock returns as an additional explanatory variable following Francis et al. (2013) and found its coefficient to be insignificant (coeff. $=0.04$, $p=0.57$ ), inconsistent with Francis et al. (2013). We also included the square of $S I Z E$ in the model, and its coefficient was insignificant. Inferences about other coefficients are the same as in Table 3.
} 
to the first announcement of the misstatement event (day 0$)^{19}$. As discussed above, a misstatement event could be revealed to the market at different times through multiple channels. Therefore, by using the earliest of all such dates (if any) as our event date, we ensure that the market model parameters are estimated without any bias. We do not estimate market model parameters if the total number of observations in the estimation period is less than 50.

The abnormal returns in the event period are calculated and accumulated as

$$
\begin{aligned}
& A R_{i, t}=R_{i, t}-\left(\widehat{\alpha}_{\iota}+\widehat{\beta}_{\imath} R_{m, t}\right) \\
& C A R_{i}^{k}=\sum_{t=-k}^{k} A R_{i, t}
\end{aligned}
$$

where $2 \mathrm{k}+1$ is the event window size, $A R_{i, t}$ is the abnormal returns to firm $\mathrm{i}$ on day $\mathrm{t}$ and $C A R_{i}^{k}$ is the cumulative abnormal returns to firm $\mathrm{i}$ in the event window.

As we explain in more detail in Appendix 1, we use two different methods to estimate the CARs. Under the first method, the event date is defined as the earliest date of publicly released information about the misstatement. As Table 2, Panel B shows, this date is the lodging date of company financials in most cases. Under the second method, we follow Karpoff et al. (2017) and examine the cumulative stock investor reaction to all relevant announcements about the misstatement event. To capture the wealth effects of these multiple announcements, we sum the firm's abnormal returns around all these event dates (if any). The CAR estimates under the second method aim to capture the cumulative reaction to the entire information flow regarding the misstatement event. For both methods, we choose $\mathrm{k}=1$ and accumulate abnormal returns over $(-1,+1)$.

To assess the robustness of our results to the choice of the econometric model, we also estimate a simple market-adjusted model in which daily abnormal returns are calculated as daily stock returns minus daily market returns. The abnormal returns are then accumulated over the same event windows as in the onefactor market model. To estimate the daily market returns, we use Datastream's value-weighted market index returns that reflect redistribution events. Finally, the existence of small or large outliers could

\footnotetext{
${ }^{19}$ We find similar results if we set the estimation period as $(-252,-6)$ trading days relative to the first announcement of the misstatement event.
} 
affect results significantly, especially in small samples. To address this possibility, we winsorize all CAR variables at their $2.5^{\text {th }}$ and $97.5^{\text {th }}$ percentiles.

We expect the announcement CARs to be lower for misstatement corrections that reduce prior-period earnings or equity than for those that do not. We therefore include an indicator variable, NEGEARNEQ, which equals unity if the net effect of the correction on prior-period earnings or equity is negative and zero otherwise. A negative relation between CARs and a negative earnings impact indicator is usually reported by U.S. studies (Files et al. 2009, Myers et al. 2013). We include variables that control for the severity of the misstatement, namely, CONSOL_EQ_TA measured as the net effect of the misstatement on shareholders' equity scaled by the total assets of the firm at the end of the year prior to the misstatement year; $R E V$, which is an indicator equal to unity if recognized revenue is corrected and zero otherwise; COREEXPENSES, which is an indicator equal to unity if operating expenses are corrected and zero otherwise; NUMERRORS, which is the number of errors associated with a misstatement; and FRAUD, which is an indicator equal to unity if the words "fraud" or "irregularity" appear in the disclosure and zero otherwise. Prior U.S. research generally finds negative coefficients for these variables. Stealth and non-stealth misstatements may affect abnormal returns differently around announcement dates. Therefore, we include an indicator, STEALTH, equal to unity for misstatements initially disclosed only in the periodic filing and zero otherwise.

We include SIZE (the natural logarithm of total assets), because investor reactions to announcements by large firms may be weaker than the reactions by small firms due to differences in their information environments (Freeman, 1987). We include $L E V$ (total liabilities divided by total assets) to control for the firm's financial risk and $R O A$ (earnings divided by total assets) to control for the firm's profitability. EARNINGS_SURPRISE measures the information content associated with earnings for misstatements that are released simultaneously with earnings announcements and is equal to the difference in net profits between the most recent and prior financial statements scaled by the total assets at the end of the previous fiscal year. Some earnings and misstatements' announcements are not released simultaneously, thus, EARNINGS_SURPRISE measured at the most recent and prior financial statements should not be an 
important explanatory variable for them. ${ }^{20}$ In untabulated tests, we estimate the models without EARNINGS_SURPRISE with no change in inferences for the test variables. ${ }^{21}$ Finally, abnormal returns are likely to behave differently during recessionary periods, so we include indicator variables for misstatements in 2008 and 2009. All variables, except for indicator and log-transformed variables, are winsorized at their $2.5^{\text {th }}$ and $97.5^{\text {th }}$ percentiles.

To examine the relationship between misstatement characteristics ${ }^{22}$ and CARs, we estimate the following OLS “cross-sectional” model (firm and year subscripts are omitted):

$$
C A R=\alpha+\beta X^{R}+\gamma X^{C}+\delta_{t}+\varepsilon
$$

where $X^{R}$ are the misstatement characteristics, $X^{C}$ are the firm-level control variables mentioned above, and indicator variables denoted by $\delta_{t}$ are included to control for industry and year fixed effects.

\section{Results}

\subsection{Univariate tests}

Table 4 presents results from one-sample mean $t$-tests for CARs calculated using various methods around misstatement announcements for the full sample and for partitions of misstatement characteristics. We conduct these univariate tests for the same sample of 594 misstatements used for our multivariate tests for comparability.

\section{Table 4 about here}

Panel A of Table 4 shows that the average three-day investor reaction to the full sample of misstatements varies between $-0.9 \%$ and $-0.1 \%$ depending on the method used to calculate CARs, and none of these means differ significantly from zero. Hypothesis 1 is not rejected. In Panel B of Table 4, we partition the sample based on each misstatement correction's effect on earnings or equity. We find that for misstatements that change earnings or equity, the mean abnormal returns differ insignificantly from zero

\footnotetext{
${ }^{20}$ We thank the reviewer for pointing out this issue.

${ }^{21}$ In other untabulated tests, we also add market-to-book ratio of equity to our specifications and obtain similar results, albeit for a smaller sample.

${ }^{22}$ Appendix 4 shows definitions of those misstatement characteristics used as control variables not explained in Appendices 2 and 3.
} 
for CARs calculated only on the initial announcement date of the misstatements (Method 1). However, for Method 2 where we sum CARs across all event dates, the mean CAR is $-1.5 \%$ for both the market beta adjustment and for the simple market adjustment, and both means are significant. For misstatement corrections that do not affect earnings or equity, none of the mean CARs is significantly different from zero. For the market-adjusted CAR means under Method 2, we find that corrections changing earnings or equity differ significantly from corrections that do not, as the two columns on the far-right show (mean diff. $=-0.019, p=0.094$ ). Hypothesis $2 \mathrm{~A}$ is rejected. These findings highlight the importance of accumulating abnormal returns over multiple event dates, as Karpoff et al. (2017) suggest. Mean CARs for misstatements that reduce earnings or equity $(N E G E A R N E Q)$ are negative for all calculation methods and significant for Method 2, with abnormal returns of $-2.3 \%(p=0.032)$ and $-2.5 \%(p=0.024)$ for the beta adjustment and market adjustment models, respectively. Mean CARs for POSEARNEQ are insignificant, indicating that investors react to misstatements with unfavourable information content more strongly, consistent with U.S. studies. Both the beta-adjusted and market-adjusted mean CARs for Method 1 are significantly lower for NEGEARNEQ than for POSEARNEQ. Hypothesis 2B is not rejected using a one-tailed test.

Panel C of Table 4 shows mean CARs for the subsample of accounting issues shown in Panel A of Table 2. No issue has an investor reaction significantly different from zero except for $R E O R G$, which has positive mean CARs of 3.3\% and 3.9\% under Method 2 for the beta adjustment and market adjustment models, respectively. Since accounting for reorganizations is complex and can affect many parts of the firm's financial statements, investors may perceive that misstatement corrections in accounting for reorganizations is accompanied by more internal control improvements than for other misstatement corrections. One can observe a positive reaction if these improvements have benefits beyond the costs of the misstatement error. The lack of significant CARs for the other accounting issues could be due to the heterogeneous information within each issue reducing the power of the tests. For example, although one expects $R E V$ corrections to attract investor attention, mean CARs are insignificant for all measures. However, if we examine those $46 R E V$ corrections that also reduce either earnings or equity, we find negative and significant mean CARs, with one as low as $-5.16 \%$ (untabulated). These results suggest 
that whether a misstatement correction reduces earnings or equity is most important for Australian investors. Panel D of Table 4 shows two severity measures of misstatements often examined in U.S. studies, namely, whether the misstatement relates to fraud, and the number of errors associated with the misstatement. For misstatements related to fraud, the three-day average abnormal returns range from $5.4 \%$ to $-8.7 \%$ and despite the small number observations, two of the CAR metrics are statistically significant, consistent with U.S. studies. We do not find significant abnormal returns for misstatements with multiple errors. Panel E of Table 4 shows mean CARs partitioned by whether the misstatement is disclosed only in the periodic filings (stealth misstatements), or otherwise (non-stealth misstatements). Consistent with the LAT, investors react more negatively to non-stealth misstatements than to stealth ones. For the 117 non-stealth misstatements in our sample, the average CARs vary between $-1.3 \%$ and $-2.7 \%$ and all differ significantly from zero. In contrast, none of the means for stealth CARs is significant. The bottom row of Panel E shows that three of the four pairs of mean CARs differ significantly from one another. We reject Hypothesis 3. The multivariate regression tests covered in the next section, provide more robust evidence on the investor reaction to misstatement news.

\subsection{Multivariate tests}

Before discussing the results of the multivariate regression tests, we present descriptive statistics of the variables used in the models. As noted, we use four CAR measures to assess the reaction around misstatement news dates, and the first four rows of Table 5 shows statistics for these variables. The standard deviations of the CARs estimated using Method 2 are higher than those estimated using Method 1. Thus, accumulating abnormal returns over multiple event dates results in more volatile CAR estimates. The mean CARs for both methods are close to zero although Method 2 yields slightly more negative CARs than Method 1 does. We do not find meaningful differences between the market model and simple market-adjusted model estimates, and the distribution of beta- and simple market-adjusted CARs seem to be comparable to each other under their respective methods.

\section{Table 5 about here}

The other rows of Table 5 show the statistics for the independent variables. The misstatement announcements in our regression sample contain information about a variety of error types made in 
earlier financial reports, such as those having a negative impact on the prior period's earnings or equity (38.9\% of the sample), those having an error for revenue recognition (13.3\%), for core expenses $(27.8 \%)$ and those associated with corporate fraud (2\%). The percentage of stealth misstatements is $80.3 \%$, meaning that fewer than $20 \%$ of the misstatement years were highlighted to the market, by, for example, a separate announcement, an ASX headline, or a re-issue of the financial report.

Table 6 shows the results from estimating model (5). The coefficients of the NEGEARNEQ dummy shown in the first row of the table indicate that the three-day abnormal returns associated with misstatements that reduce earnings or equity vary between $-1.1 \%$ and $-2.8 \%$. These coefficients are statistically significant when abnormal returns are cumulated over multiple event dates (Method 2), implying that unfavourable misstatements are penalized by the market around dates other than the initial revelation date. These results are consistent with the univariate results in Table 4 . The magnitude of the misstatement correction, namely $C O N S O L_{-} E Q_{-} T A$, has positive coefficients across all specifications, but no coefficient is significant. $R E V$ has a negative coefficient in all specifications that ranges from 0.005 to -0.017 and the coefficients estimated using Method 1 are significantly different from zero and consistent with expectations. This result leads us to reject Hypothesis 2C. The coefficient estimate for COREEXPENSES is insignificant, inconsistent with U.S. studies.

\section{Table 6 about here}

Although the coefficient estimates for FRAUD are high and a misstatement that is associated with fraud has an average incremental abnormal return of between $-3.3 \%$ and $-4.7 \%$, none of these coefficients are significant, potentially due to the lack of statistical power driven by the small number of observations for FRAUD. However, the coefficient estimates for the STEALTH dummy are reliably positive in all specifications. They range from 0.013 to 0.025 and indicate that misstatement firms that do not draw attention to their errors experience CARs between $1.3 \%$ and $2.5 \%$ higher than misstatement firms that highlight their errors. Managers who highlight the error may believe that their firms' cost of capital will be lower as a result or are naïve to the consequences (Files et al. 2009). The number of errors in a misstatement has no relation with abnormal returns. Regarding the control variables, ROA loads 
positively under Method 2 for the simple market adjustment and EARNINGS_SURPRISE loads positively under Method 1.

The insignificance of the misstatement characteristics' coefficients could be due to the assumption in model (5) that the characteristics' effects are the same across all observations. Prior research has shown that misstatements disclosed 'stealthily' are associated with less pronounced negative investor reactions on announcement dates (Files et al., 2009; Myers et al., 2013). We examine whether the level of 'stealth' of misstatement disclosures moderates the relation between CARs and misstatement characteristics by interacting the STEALTH dummy with misstatement characteristics.

\section{Table 7 about here}

Table 7 shows the results of estimating Model 5 including the STEALTH indicator and its interaction with misstatement characteristics. This new model is denoted Model (6). NEGEARNEQ has a significantly negative coefficient in all specifications with values between -0.028 and -0.064 , indicating that when misstatements that reduce earnings or equity are disclosed more saliently (non-stealth ones), abnormal returns of between $-2.8 \%$ and $-6.4 \%$ are observed for them. On the other hand, the coefficients on the interactions of $N E G E A R N E Q$ with the stealth dummy, denoted by $N E G E A R N E Q I N T$, have positive coefficients that are significant when measured by accumulating across all relevant misstatement events. For these models, misstatements that reduce earnings or equity and are not disclosed saliently (stealth misstatements) have abnormal returns of $-2.1 \%(-0.064+0.043$ or $0.063+0.041$ ), or approximately 4 percentage points less negative than non-stealth misstatements. In other words, investors penalize highlighted bad news more than bad news disclosed stealthily, a result that is consistent with the LAT and U.S. research (Files et al. 2009, Myers et al. 2013). We reject Hypothesis 3. CONSOL_EQ_TA and its interaction with the stealth dummy (CONSOL_EQ_TA_INT) have insignificant coefficients and $R E V$ also loses its significant coefficient in Table 6 when the interaction term is introduced. It seems that disclosure saliency does not affect investors' perceptions of revenue corrections, which is inconsistent with the LAT. However, of the 79 revenue adjustments in

this sample, only 19 are non-stealth ones, suggesting that low power could explain the insignificance of REV_INT. Under Method 2, COREEXPENSES has a significantly positive coefficient, and its interaction 
with the stealth dummy has a significantly negative coefficient, which is very similar in absolute magnitude to that of COREEXPENSES. In other words, non-stealth misstatements that are core expenses have positive reactions, but when the same news is disclosed stealthily, the reaction vanishes. Although this result is inconsistent with our expectations, we believe it is likely to be a statistical artefact given that it appears only in one of the four model estimations. Among the other misstatement characteristics and firm-level control variables, the STEALTH and EARNINGS_SURPRISE variables have significantly positive coefficients, but only when beta-adjusted CAR variables estimated with Model 1 are used as dependent variables.

\subsection{Additional tests}

Untabulated statistics show that for 525 of 703 firm-years ${ }^{23}$, disclosure of the misstatement news occurs on the earnings announcement date, suggesting that earnings news could attenuate the reaction to misstatement news. ${ }^{24}$ We conduct additional tests to shed light on this potential explanation for our results. Most of these additional test results are not tabulated for brevity. First, we examine if the EARNINGS_SURPRISE control variable affects the inferences about our test variables. We estimated Models 5 and 6 without EARNINGS_SURPRISE. We then re-measured earnings surprise by creating dummies equal to unity if the magnitude of earnings surprise is in the bottom or top $5^{\text {th }}, 10^{\text {th }}$ and $25^{\text {th }}$ percentiles, and if the earnings surprise is positive and then by scaling the change in earnings by the beginning of fiscal year market value of equity instead of total assets. We also ran our tests on a smaller sample totalling 90 observations, by using the mean/median consensus analysts' earnings estimate minus the actual earnings standardized by the absolute value of the mean/median consensus analysts' earnings estimate (Duru and Reeb, 2002) instead of EARNINGS_SURPRISE. Estimates for the test variables from all these regressions are similar to those in Tables 6 and 7, although we do observe a negative coefficient for STEALTH coefficient when we used the analysts' forecasts to measure earnings surprise. $^{25}$

\footnotetext{
${ }^{23}$ One firm did not disclose its current-year earnings, but it did disclose sufficient information about its error for inclusion in our dataset totalling 704 firm years.

${ }^{24} \mathrm{We}$ are grateful to an anonymous reviewer for this suggestion.

${ }^{25}$ We were able to match 167 observations with the IBES database but there were many stale-date forecasts. When
} 
Second, we split the sample based on whether disclosure of the misstatement news occurred on the same date as the earnings announcement or not, and estimated the model for each group. ${ }^{26}$ Results showed that $N E G E A R N E Q$ and $R E V$ were generally negative and significant for the group where disclosure of misstatement news occurred on the same date as the earnings announcement; and $R E V$ was generally negative and significant for the other group. We further examined the weak results for the test variables for the sample where disclosure of the misstatement news occurred on a different date than earnings, by removing STEALTH, outliers greater than $5 \%$ of the regression residuals and then the dummy controls. ${ }^{27}$ These extra tests did not change our inferences about the test variables. To formally test for differences between these two groups, we interacted the misstatement test variables with a dummy equal to unity when disclosure of the misstatement news occurred on the same date as the earnings announcement and zero otherwise (NEWS_SAME_EARN), and included these variables in the model. Results, using the full sample, showed that the coefficients for the interactions with REV and with COREEXPENSES are significant and positive for two of the regressions; indicating that returns are weaker for revenue and core expenses adjustments when they are disclosed on the earnings announcement date. This finding is consistent with the idea that earnings news attenuates the investor reaction to misstatement news. A possible reason for the insignificance of the coefficient on the NEWS_SAME_EARN and NEGEARNEQ interaction is, that the magnitudes of the earnings' corrections could be smaller when disclosed on a different date to the earnings announcement, than when they are not; and that the market regards small magnitudes of $N E G E A R N E Q$ as less important than large magnitudes. Therefore, as our final test, we explored the effect of differences in magnitude of error corrections on these results for NEGEARNEQ. We compared the means and medians of the percentage changes in earnings for NEGEARNEQ between the two groups. ${ }^{28}$ Results showed that the NEGEARNEQ variable's means and medians are significantly lower for the group whose misstatement news is released on the earnings announcement date. We then estimated a logit regression where the dependent variable is NEWS_SAME_EARN. Given the univariate

we limit the sample to those forecasts within 31 days before the earnings announcement date, our sample size fell to 90 observations. The coefficient estimate for earnings surprise was generally insignificant in these regressions.

${ }^{26}$ The sample size for misstatements news released on the same (different) date as earnings totals 452 (142).

${ }^{27}$ We thank the reviewer for suggesting these tests.

${ }^{28}$ We use earnings here rather than equity because a large portion of earnings corrections are due to share-based payment errors, which have no effect on equity. Using equity would eliminate these corrections from this analysis. 
results, we included the following variables in this regression: NEGNI_EFFECT_BIG measured as unity if the correction to earnings is negative and large (defined as less than the median of negative earnings corrections) and zero otherwise; NEGNI_EFFECT_SMALL measured as unity if the correction to earnings is negative and it is small and zero otherwise; and POSNIEFFFECT measured as unity if the correction to earnings is positive and zero otherwise. Misstatement error corrections that do not change earnings are the reference group. The percentages of sample observations are 16,16,17 and 51 for each of these four groups, respectively. We included REV, COREEXPENSES, FRAUD, NUMERRORS and MISSTATEMENTLAG in the model because each of these variables measures attributes of more serious misstatements. STEALTH is included because firms that disclose misstatement news only in a periodic filing may also release that news on the earnings announcement date. ${ }^{29}$ The other control variables are SIZE, LEV, ROA, BIG4 and AGE. The results in the first two columns of Table 8, show that NEGNI_EFFECT_BIG, REV and COREEXPENSES have higher odds of disclosure on the earnings announcement date than non-core earnings corrections and those that do not affect earnings. Corrections for older errors and errors reported only in periodic filings are more likely to be disclosed on the earnings announcement date, as the positive coefficients for MISSTATEMENTLAG and STEALTH indicate. We find that the odds are higher for fraud-related misstatement news to be disclosed on a date other than the earnings announcement date. No control coefficient is significant except for SIZE and $A G E$. Larger (older) clients have higher (lower) odds of disclosing misstatement news on the earnings announcement date. To further explore the relations between NEWS_SAME_EARN, STEALTH and the misstatement variables, we interacted the misstatement variables with STEALTH. Results in the last two columns of Table 8 show that all interaction coefficients are insignificant; indicating no difference in the saliency of these corrections. Results (untabulated) from t-tests and Wilcoxon tests of differences in the percentage change in earnings for the stealth versus non-stealth groups for the sample where misstatement news is disclosed on the earnings announcement date; are insignificant, consistent with these regression results. We also estimated the model on the sample of firms that announce their earnings on the same date as the release of misstatement news $(\mathrm{N}=452)$, and the coefficient for the interaction

29 The correlation coefficient between STEALTH and NEWS_SAME_EARN is +0.57 , suggesting that multicollinearity is unlikely to cause problems with the estimates. 
term between STEALTH and NEGEARNEQ is highly significant and positive. This finding is consistent with the results in Table 7 and the argument that disclosure saliency improves the impounding of misstatement information into prices. ${ }^{30}$ Taken together, these additional test results suggest that the weaker investor reactions for negative earnings or equity corrections and for core expenses, reported in Tables 6 and 7, are due to the more important types of earnings corrections disclosed on the same date as earnings is announced, and that investor attention is limited.

\section{Summary and conclusions}

This paper provides evidence on the quality of Australia's financial reporting, recently been called into question by the ASIC. For ASX-listed firms over an eight-year period through 2013, we document accounting misstatement frequency, misstatement severity and the timeliness of disclosures about misstatements. We examine investor reaction to the announcement of misstatement news and to various accounting issues associated with misstatements. Our tests shed light on whether Australian stock market participants treat misstatements as 'bad news', speaking to the quality of financial reporting in Australia. In a test of the limited attention theory (LAT) and following recent U.S. research, we also examine whether misstatement disclosure salience is an important moderator in the relation between misstatement announcement returns and misstatement issues.

We find $4.1 \%$ of firm-years with a misstatement. The percentages vary widely by year, with the peak of $6.3 \%$ in the 2009 year and the minimum of $3.4 \%$ in the 2013 year. We find that for $79 \%$ of misstatement firm years, firms do not highlight their errors by disclosing them, for example, in a press release, in a separate note, or in the ASX announcement heading. Instead, these errors are disclosed only in the halfyear or annual financial reports. Consequently, investors seem to wait for almost 8 months (the median is 239 days) for news about most misstatements. Consistent with prior U.S. evidence, most misstatements that correct prior-period earnings or equity are negative - the median percentage

\footnotetext{
${ }^{30}$ For the sample where $N E G E A R N E Q=1$, we performed t-tests and Wilcoxon tests of the difference in the percentage change in earnings and of the difference in the percentage change in equity, between the stealth and non-stealth groups for the sub-sample that released misstatement news on the same date as earnings news. All $p$ values (two-tailed) from these tests were above 0.3. Given that the mean/median differences for the percentage change in earnings for $N E G E A R N E Q$ are insignificant, magnitudes of this type of misstatement correction across the stealth and non-stealth categories are not likely to explain the results.
} 
decreases are 4.9 and 1.3, respectively. We find that large negative earnings, revenue, and core expenses corrections, are more likely to be disclosed on the same date as earnings is announced, than other types of misstatement corrections. This evidence is consistent with ASIC's recent concerns about financial reporting quality in Australia. We acknowledge an unavoidable limitation common in this research stream, namely, that unreported errors may affect our inferences. ${ }^{31}$

Regarding investor response to misstatement news, univariate tests show that CARs centred on the announcement date are insignificant for the full sample, but are equal to $-1.5 \%$ for misstatements that change earnings or equity and $-2.4 \%$ for those that reduce earnings or equity. In multivariate tests, misstatements that reduce earnings or equity have a coefficient estimate of $-2.8 \%$, and misstatements that affect revenue have a coefficient estimate of $-1.7 \%$. We find that firms that disclose misstatements less saliently experience CARs of between $1.3 \%$ and $2.7 \%$ higher than the firms that highlight them. Higher disclosure saliency increases the strength of the negative reaction to misstatements that reduce earnings or equity, consistent with the LAT and U.S. evidence. We find little evidence of reactions for most accounting issues associated with misstatements.

Collectively, our evidence indicates that investors generally react to the more serious accounting misstatements and the reactions are less negative and weaker for misstatements disclosed stealthily. For policymakers, our study has two takeaway messages. First, conditional on detected misstatements being disclosed, accounting quality in Australia seems to have improved in recent years using misstatement frequency as the quality proxy, suggesting that major changes to current oversight work are not required. Finally, while the frequency of misstatements has fallen, the majority of misstatement disclosures have low saliency, possibly contributing to a sluggish impounding of that information into prices. Pronouncements that improve disclosure saliency could be beneficial to market pricing.

\footnotetext{
${ }^{31}$ We thank an anonymous reviewer for noting this.
} 


\section{Appendix 1 - Sample construction method}

\section{A.1 Identification of a misstatement}

We use the definition from Auditing Standard ASA 200, Overall Objectives of the Independent Auditor and the Conduct of an Audit in Accordance with Australian Auditing Standards, to identify a misstatement for inclusion in our dataset, namely, “...a difference between the amount, classification, presentation, or disclosure of a reported financial report item and the amount, classification, presentation, or disclosure that is required for the item to be in accordance with the applicable financial reporting framework. Misstatements can arise from error or fraud." (ASA200, para 13.4(i)). We further refine our scope by including only misstatements of audited accounting information. Thus, we exclude misstatements of items in interim financial reports of other unaudited accounting information, such as unaudited preliminary reports. We exclude firms that do not comply with Australian GAAP, such as foreign firms and entities that prepare special-purpose financial reports, in the interest of consistency in financial reporting regulatory requirements. We also exclude firms that misstated a reporting period prior to listing but disclosed the error after listing. For these firms, it is unclear if the misstated accounts had to be audited. We exclude re-issuances of financial reports for administrative reasons, such as cases in which the wrong reports were lodged or typographical errors were made. Consequently, our reported error frequencies are less than the total frequency of errors in accounting information lodged with the ASX.$^{32}$ Misstatements caused by accounting policy and accounting standard changes, tax rate changes, revisions of acquisition accounting attributable to new information, misstatements caused by discontinued operations and capitalization changes (e.g., bonus share issues) are excluded because they do not meet the definition above. ${ }^{33}$ Thus, our dataset includes both errors in audited financial statements (see AASB 108, para 5) and errors in and omissions from remuneration information in the directors'

\footnotetext{
${ }^{32}$ In recent years, the re-issuance of audited accounts has become more common. Often, a firm provides no information about the reason for the re-issuance. As noted, we only included these firms when earnings or equity changed and it was clear that the reason for the re-issuance was an error. This aspect of our data-collection method understates the quantity of misstatements at a further extent in more recent times.

${ }^{33}$ Some misstatements disclosed as accounting policy changes could be errors. As an example, Medtech Global Limited preliminary financial report for 2010 disclosed the reason for its 2009 financial report misstatement as an error, but its audited financial report disclosed the reason as an accounting policy change.
} 
report for firms listed on the ASX that comply with Australian GAAP and prepare general-purpose financial reports.

\section{A.2 Information Sources for Misstatements}

The first source of information is half-year and annual audited financial reports lodged with the ASX for all listed and delisted firms from January 2006 through April 2014. Since our final sample financial year is 2013, we search until 30 April 2014 to allow sufficient time for December-year-end firms to lodge their annual accounts. These reports were searched for the following keywords: "amend" or "restate" or "correct" or "prior period" or "prior-period" or "prior year" or "prior-year" or "error" or "revise" or "investigat" or "errat" or "replace" or "irregular" or re-issue" or "reissue" to provide a list of possible misstatements. Two research assistants independently read each case of a potential misstatement and coded them as a "misstatement" or "unknown". The percentage of agreement between them for "misstatement" was $65 \%$. An author of this paper checked the coding and corrected it where necessary.

Our second source of information is the content of ASX announcements. Specifically, for each misstatement identified in the financial report, we search the content of all ASX announcements lodged in the period since the previous audited annual financial report, a period up to nine months, for the abovementioned keywords. We read each announcement and recorded the dates of announcements about the misstatement. For misstatements disclosed in the annual reports, we found only a small number of announcements outside half-year financial reports indicating that most misstatements are stealth (see Table 2, Panel B). When we locate news about a misstatement in a transcript, we use the date of the podcast, because transcripts are usually lodged after the podcast (see, for example, KMD's transcript of 16 November 2012 lodged on the ASX website on 19 November 2012). For misstatements that change recognized information, we also examined the previously-lodged financial reports within this period. We found several cases were firms changed comparatives in line with the correction of the error, but gave no other information about the misstatement at that time. We recorded the dates and relevant information for these observations. These observations raise an issue about event dates, which we 
discuss below. We did not search the content of all ASX announcements for all listed firms because of the large size of that task and we acknowledge this limitation in our data-collection method.

Our third information source is the ASX announcement headlines. We searched for the abovementioned keywords in these headlines for all listed and delisted firms from January 2006 through April 2014. We identified several misstatements disclosed by re-issuing a financial report or portions thereof were in this search. We found a number of cases where amended audited financial reports were reissued on the same day or shortly after the original audited financial reports' releases, but with no information about the reason for the re-issuances. We yielded to the size of the task of comparing all the information across both financial reports and compared only the two sets of financial statements for evidence of a misstatement. In this manner, we found one misstatement case. We acknowledge this limitation in our data-collection method.

Our fourth source of misstatement information is action against the companies or their directors. We read all ASIC media releases ${ }^{34}$ from the ASIC website from 2006 to 2013 and recorded dates for which we found information about a misstatement case. Most of these dates are stale; that is, they were released after other releases.

Our fifth source of information is press releases. We searched Factiva and Google News for all Australian publications from 2006 to 2013 for the abovementioned keywords and then for the names of all ASX-listed companies in a second search. We used the current names for each financial year since some Australian firms change their names. Most of the data obtained from these sources were for firms already identified using the above sources and were stale. However, we did identify a small number of extra cases using this second search, such as Westpac's 2006 misstatement, described as an "overaccrual".

We recorded the date of public release for each misstatement event for each of these sources.

\footnotetext{
${ }^{34}$ ASIC releases information about its investigations, including those under s13 of the ASIC Act 2001, and regulatory actions such as enforceable undertakings. ASIC's policy statement is available at: http://download.asic.gov.au/media/1339124/INFO_152_Public_Comment.pdf
} 


\section{A.3 Identification of misstatement event dates}

We list all dates about the misstatement from the sources mentioned above.

As noted, in examining the ASX announcements, we examined the comparatives of the financial reports lodged prior to the misstatement financial report to determine whether they were changed in line with what was disclosed in the misstatement financial report. We found some firms did so for no stated reason, a situation that occurred most often in unaudited preliminary reports and sometimes in other reports such as half-year reports. One example is World Titanium Resources Limited's (previously Bondi Mining Limited) reclassification of its cash and accounts payable balances on 30 June 2010. The reclassification occurred first in its 31 December 2010 half-year report, lodged with the ASX on 15 March 2011. An explanation for this reclassification occurred first in its June 2011 annual financial report, lodged with the ASX on 27 September 2011. Since the reason for the change was known at its half-year lodgement date but not explained to the market at that time, we record the date of 15 March 2011. It is arguable whether dates such as 15 March 2011 for World Titanium Resources Limited are the "earliest release dates" in our study because firms can change recognized information for accounting policy changes, for example. In our main tests, we do not use these dates as the earliest release date; rather, we use the earliest date when the information about an error was released.

As in Karpoff et al. (2017), we sum the abnormal returns over all unique event dates in our Method 2. Specifically, we examine each disclosure of error information and identify those disclosures that are materially different from the previously disclosed information. Some judgement is used. For example, if a firm changed the amount of the correction to the prior period but that change is less than $5 \%$ of the previous amount, we exclude it. If a firm provided only the restated prior-period half-year earnings in the initial disclosure, perhaps because its initial disclosure was included in the half-year accounts, and provided the restated annual earnings in its annual accounts, then we include it. We also include cases in which the comparatives were changed in line with the restated accounts, with no other information 
about the error. In other cases, it is clear that the information is "new". For example, a new error may be disclosed in subsequent releases and cause material changes to the number of existing errors.

\section{A.4 Classification of Accounting Issues}

Our research assistants classified the errors into accounting issues following the Audit Analytics method in Scholz (2013), in the absence of an Australian classification scheme and for comparability with similar studies. Appendix 2 shows the accounting issue definitions and descriptions for this scheme. Because U.S. GAAP differs from Australian GAAP, we modified the classification scheme by including misstatements of upward noncurrent asset revaluations in the INVESTING category and misstatements

of audited information in director's reports in the FNOTEDIR category. An author of this paper checked the coding and made necessary changes.

\section{A.5 Identification of date of most recent incorrect accounts}

The variable Error lag is measured as the number of days since the last lodging of an audited annual financial report with no information about the misstatement. In most cases, this date is the most recent lodging date of the prior year's annual financial report. In some cases, we use the preliminary report for the misstatement year when it is audited, provided that the error relates to a disclosure contained therein. For example, some disclosures, such as detailed executive remuneration disclosures, are not required in the preliminary report, thus, assigning the date of the preliminary report to an error would be inappropriate. In such cases, we use the previous year's annual report lodging date instead. 
Appendix 2 - Variable Names and Variable Definitions for Accounting Issues

\begin{tabular}{ll}
\hline Variable Name $\quad$ Variable Definition \\
\hline
\end{tabular}

Accounting Issues: Business activities

REV The error is associated with revenue recognition.

EXPACCRESEST The error is associated with the expensing of assets or understatement of liabilities, the accrual or identification of liabilities on the balance sheet, or with cash, accounts receivable, loans collectible, investments allowance for uncollectables, notes receivable, or related reserves.

EXPSTOCK The error is associated with the recording of deferred, stock based or executive compensation.

EXPCOS The error is associated with transactions affecting inventory, vendor relationships or cost of sales.

EXPCAPDEPAM The error is associated with the capitalization of expenditures or depreciation of assets, amortization of assets or amortization of debt premiums or discounts.

EXPPENCONLEA The error is associated with pensions or other post-retirement plans or benefits or leases.

TAX The error is associated with various forms of tax obligations or benefits.

INVESTING The error is associated with the recording of assets, goodwill, intangible or contra liabilities that are required to be valued or assessed for diminution in value on a periodic basis, the recording of gains or losses from the sales of assets, interests, entities or liabilities, or upward revaluations of non-current assets.

FINANCING The error is associated with the recording of debt or equity accounts or derivative instruments.

Accounting Issues: Financial statement presentation

CFMISS The error is associated with the cash-flow statement classification errors.

ISMISSEPS The error is associated with the disclosure of financial/operational ratios or margins and earnings per share calculation issues or where income statement items are misclassified instruments.

DEQMISS The error is associated with the proper classification of a debt instrument as short term or long term or between debt and equity accounts.

FNOTEDIR The error is associated with a financial statement, footnote or segment reporting information or the director's report.

ASSETMISS The error is associated with how assets were classified on the balance sheet.

COMPINC The error is associated with comprehensive income.

Accounting Issues: Subsidiary accounting and atypical transactions

SUBSID The error is associated with intercompany or associate balances, investment valuations or transactions, disclosures about related, alliance, affiliated or subsidiary entities.

CONSOL The error is associated with the consolidation of subsidiaries, off balance sheet arrangements and joint ventures.

REORG The error is associated with mergers, acquisitions, disposals, reorganizations or discontinued operation accounting issues.

Accounting issues in Panel A are adapted from Audit Analytics as in Scholz (2013). 


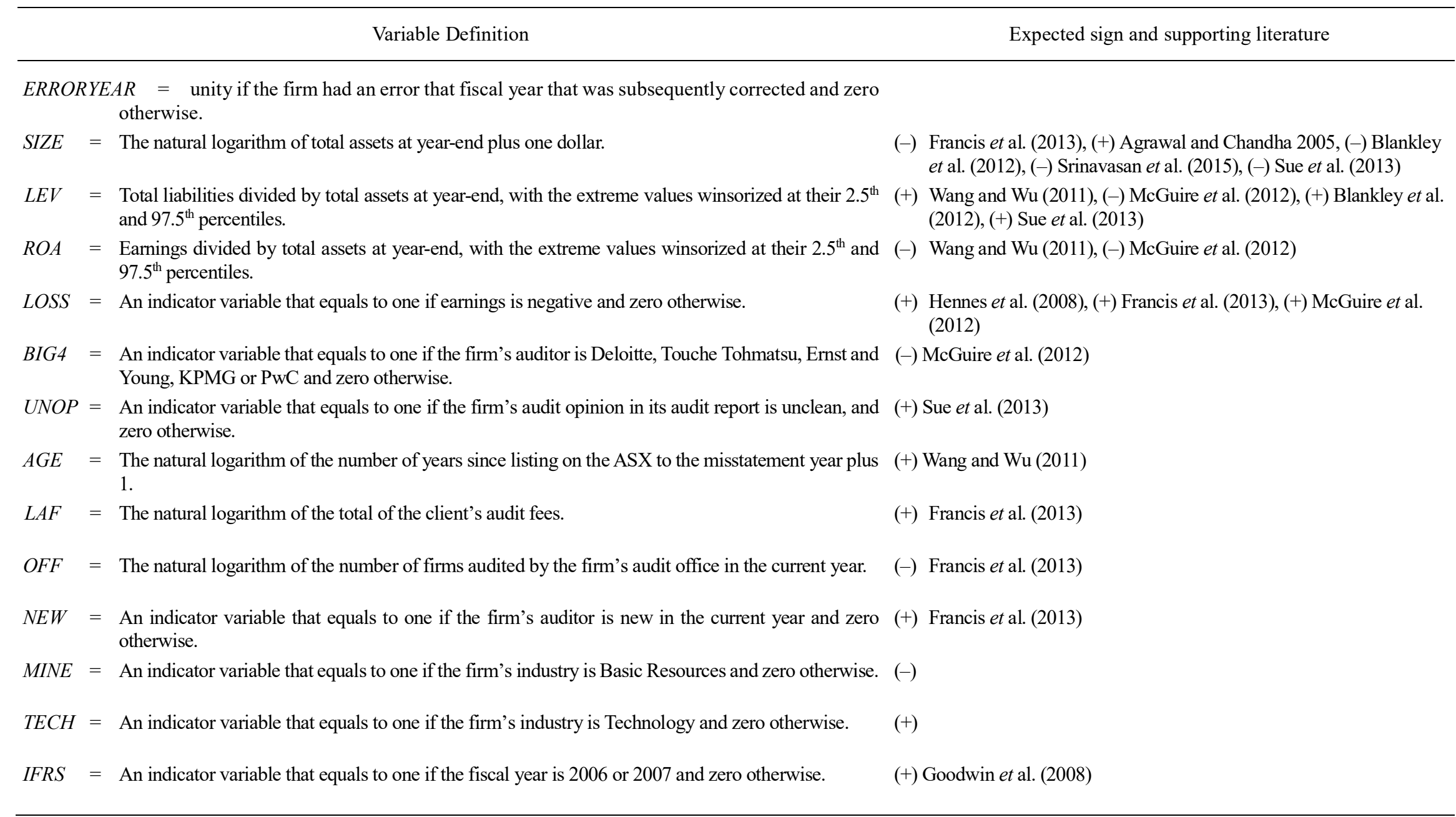


Appendix 4 - Extra Variable Names and Variable Definitions for Variables used in Tests

\begin{tabular}{|c|c|}
\hline Variable Name & Variable Definition \\
\hline COREEXPENSES & $\begin{array}{l}\text { Unity if an accounting issue is for } E X P A C C R E S E S T, E X P S T O C K, E X P C O S \text {, } \\
\text { EXPCAPDEPAM or EXPPENCONLEA and zero otherwise. }\end{array}$ \\
\hline CONSOL_EQ_TA & $\begin{array}{l}\text { The amount of the correction to opening equity divided by total assets at the } \\
\text { end of the prior financial year. }\end{array}$ \\
\hline EARNINGS_SURPRISE & $\begin{array}{l}\text { The change in earnings scaled by beginning of period total assets. When a } \\
\text { misstatement is initially disclosed in half-year accounts, we measure change } \\
\text { in earnings as half-year earnings less the previous corresponding half-year } \\
\text { earnings as disclosed in those half-year accounts. Otherwise we measure } \\
\text { change in earnings as annual earnings less the previous years' annual } \\
\text { earnings as disclosed in those annual accounts. }\end{array}$ \\
\hline FRAUD & $\begin{array}{l}\text { Unity if the words "fraud" or "irregularity" appear in the disclosure and zero } \\
\text { otherwise. }\end{array}$ \\
\hline MISSTATEMENTLAG & The number of years from the misstatement year to the earliest error year. \\
\hline NEGEARNEQ & $\begin{array}{l}\text { Unity if the net effect on prior period's consolidated earnings or equity is } \\
\text { negative and zero otherwise. }\end{array}$ \\
\hline NEGNI_EFFECT_BIG & $\begin{array}{l}\text { Unity if the percentage change to earnings is negative and is less than the } \\
\text { median of all negative percentage changes to earnings and zero otherwise. }\end{array}$ \\
\hline NEGNI_EFFECT_SMALL & $\begin{array}{l}\text { Unity if the percentage change to earnings is negative and is greater than or } \\
\text { equal to the median of all negative percentage changes to earnings and less } \\
\text { than zero and zero otherwise. }\end{array}$ \\
\hline NEWS_SAME_EARN & $\begin{array}{l}\text { Unity if the initial disclosure about the misstatement error is on the same date } \\
\text { as the earnings announcement date and zero otherwise. }\end{array}$ \\
\hline NONSTEALTH & $\begin{array}{l}\text { Unity if there is disclosure about the misstatement error other than in the } \\
\text { Half-Year Report or the Financial Year Report and zero otherwise. }\end{array}$ \\
\hline NUMERRORS & The number of errors associated with a misstatement. \\
\hline POSEARNEQ & $\begin{array}{l}\text { Unity if the net effect on prior period's consolidated earnings or equity is } \\
\text { positive and zero otherwise. }\end{array}$ \\
\hline POSNI_EFFECT & Unity if the percentage change to earnings is positive and zero otherwise. \\
\hline STEALTH & $\begin{array}{l}\text { Unity if the error is disclosed in the Half-Year Report or the Financial Year } \\
\text { Report and there is no additional disclosure about the misstatement and zero } \\
\text { otherwise. }\end{array}$ \\
\hline
\end{tabular}




\section{References}

Adams, J.C., D.K. Hayunga, and S.J. Rasmussen, 2015, The restating of financial statements by REITs, Journal of Accounting Auditing and Finance, 1-22.

Agrawal, A., and S. Chandha, 2005, Corporate governance and accounting scandals, Journal of Law and Economics 48, 371-406.

Ahmed, K., and J. Goodwin, 2007, An empirical investigation of earnings restatements by Australian firms, Accounting \& Finance 47, 1-22.

Anderson, K.L., and T.L. Yohn, 2002, The effect of 10-k restatements on firm value, information asymmetries, and investors' reliance on earnings, Working paper (Georgetown University): http://papers.ssrn.com/sol3/papers.cfm?abstract_id=332380

Atiase, R. K., 1985, Predisclosure information, firm capitalization and security return behavior around earnings announcements, Journal of Accounting Research 23, 21-36.

Ball, R., A. Robin, and J.S. Wu, 2003, Incentives versus standards: properties of accounting income in four East Asian countries, Journal of Accounting and Economics 36, 235-270.

Bardos, K.S., J.H. Golec, and J. P. Harding, 2013, Litigation risk and market reaction to restatements, Journal of Financial Research 36, 19-42.

Blankley, A.I., D.N. Hurtt, and J.E. MacGregor, 2012, Abnormal audit fees and restatements, Auditing: A journal of Practice and Theory 31, 79-96.

Cochran, W.G., and G.M., Cox, G.M., 1950. Experimental Design, $1^{\text {st }}$ Ed., John Wiley, New York.

DeFond, M. and J. Zhang, 2014, A review of archival auditing research. Journal of Accounting and Economics 58, 275-326.

Desai, H., C.E. Hogan, and M.S. Wilkins, 2006, The reputational penalty for aggressive accounting: earnings restatements and management turnover, The Accounting Review 81, 83-112.

Doyle, J.T., Ge, W., and McVay, S.E., 2007, Determinants of weaknesses in internal control over financial reporting, Journal of Accounting and Economics 44, 93-223.

Duru, A., and Reeb, D.M., 2002. International diversification and analysts' forecast accuracy and bias. The Accounting Review 77, 415-433.

Elliott, J.A., and J. D. Hanna, 1996, Repeated accounting write-offs and the information content of earnings, Journal of Accounting Research 34, 135-155.

Fama, E.F., 1970, Efficient capital markets: a review of theory and empirical work, The Journal of Finance 25, 383-417.

Fama, E.F., and K.R. French, 1993, Common risk factors in the returns on stocks and bonds, Journal of Financial Economics 33, 3-56.

Fan, J., and T.J. Wong, 2002, Corporate ownership structure and the informativeness of accounting earnings in East Asia, Journal of Accounting and Economics 33, 401-425. 
Ferreira, M.A., and P.P. Matos, 2008, The colors of investors' money: the role of institutional investors around the world, Journal of Financial Economics 88, 499-533.

Files, R., D.E.P. Swanson, and S. Tse, 2009, Stealth disclosure of accounting restatements, The Accounting Review 84, 1495-1520.

Files, R., N.Y. Sharp, and A.M. Thompson, 2014, Empirical evidence on repeat restatements, Accounting Horizons 28, 93-123.

Francis, J.R. and J.L. Gunn, 2015, Industry Accounting Complexity and Earnings Properties: Does Auditor Industry Expertise Matter? Working paper:

https://www.uts.edu.au/sites/default/files/AccDG_Francis\%20Gunn_WP\%202015.pdf

Francis, J., P.N. Michas, and M. Yu, 2013, Office size of Big 4 auditors and client restatements, Contemporary Accounting Research 30, 1626-1661.

Francis, J., and M.D. Yu, 2009, Big 4 office size and audit quality, The Accounting Review 84, 15211552.

Freeman, R.N., 1987, The association between accounting earnings and security returns for large and small firms, Journal of Accounting and Economics 9, 195-228.

Gallagher, D. R., P. A. Gardner, and P. L. Swan, 2013, Governance through trading: institutional swing trades and subsequent firm performance, Journal of Financial and Quantitative Analysis 42, 427-458.

Gleason, C. A., N.T. Jenkins, and W.B. Johnson, 2008, The contagion effects of accounting restatements, The Accounting Review 83, 83-110.

Goodwin, J., B. Cooper, and S. Johl, 2008, How prepared was Australia for international financial reporting standards? The case of listed firms, Australian Accounting Review 18, 35-45.

Gow, I.D., G. Ormazabal, and D.J. Taylor, 2010, Correcting for cross-sectional and time-series dependence in accounting research, The Accounting Review 85, 483-512.

Griffin, J.M., Hirschey, N.H., and P.J. Kelly, 2011, How important is the financial media in global markets? The Review of Financial Studies 24, 3941-3992.

Hennes, K., A. Leone, and B. Miller, 2008, The importance of distinguishing errors from irregularities in restatement research: the case of restatements and $\mathrm{CEO} / \mathrm{CFO}$ turnover, The Accounting Review 83, 1487-519.

Hirschey, M., K.R. Smith, and W.M. Wilson, 2015, The timeliness of restatement disclosures and financial reporting credibility, Journal of Business Finance \& Accounting 42, 826-859.

Hirshleifer, D., and S.H. Teoh, 2003, Limited attention, information disclosure, and financial reporting, Journal of Accounting and Economics 36, 337-386.

Hribar, P., and N.T. Jenkins, 2004, The effect of accounting restatements on earnings revisions and the estimated cost of capital, Review of Accounting Studies 9, 337-356.

Kahneman, D., 1973. Attention and Effort (Prentice-Hall Inc., Englewood Cliffs, NJ.)

Karpoff, J.M., A. Koester, D.S. Lee, and G.S. Martin, 2017, Proxies and databases in financial misconduct research, Accounting Review 92, 129-163. 
Kinney, W.R. Jr., and L. S. McDaniel, 1989, Characteristics of firms correcting previously reported quarterly earnings, Journal of Accounting and Economics 11, 71-93.

Legg, M.J., 2008, The transformation of a share price fall into litigation - shareholder class actions in Australia, Paper presented at the Corporate Law Teachers Association Conference, Sydney. http://www.clta.edu.au/professional/papers/conference2008/2008ML_TSPFL.pdf

Luo, X., R. Zhang, W. Zhang, and J. Aspara, 2014, Do institutional investors pay attention to customer satisfaction and why? Journal of the Academy of Marketing Science 42, 119-136.

McGuire, S.T., T.C. Omer, and N.Y. Sharp, 2012, The impact of religion on financial reporting irregularities, The Accounting Review 87, 645-673.

Morabito, V., 2010, An empirical study of Australia's class action regimes, second report, Australian Government, Australian Research Council:

http://globalclassactions.stanford.edu/sites/default/files/documents/Vince\%20Morabito\%202nd\%20Re port.pdf

Murphy, J.B., 2013, The operation of Australia's class action regime-2013:

http://www.austlii.edu.au/au/journals/FedJSchol/2013/43.html

Myers, L., S. Scholz and N.Y. Sharp, 2013, Restating under the radar? Determinants of restatement disclosure choices and the related market reactions, Working paper (University of Arkansas).

Owers, J.E., C.M. Lin, and R.C. Rogers, 2002, The informational content and valuation ramifications of earnings restatements, International Business and Economics Research Journal 1, 71-84.

Palmrose, Z., V.J. Richardson, and S. Scholz, 2004, Determinants of market reactions to restatement announcements, Journal of Accounting and Economics 37, 59-89.

Palmrose, Z., and S. Scholz, 2004, The circumstances and legal consequences of non-GAAP reporting: Evidence from restatements. Contemporary Accounting Research 21, 139-180.

Scholz, S., 2008, The changing nature and consequences of public company financial restatements 1996-2007, The Department of Treasury, April. Available at:

http://www.lexissecuritiesmosaic.com/uploaded/ResourceCenter/FinancialRestatements_1997_2006.p $\underline{\mathrm{df}}$

Scholz, S., 2013, Financial restatement trends in the United States: 2003:2012, Center for Audit Quality, Washington, D.C: http://thecaq.org/reports-and-publications/financial-restatement-trends -in-theunited-states-2003-2012/financial-restatement-trends-in-the-united-states-2003-2012

Sellars, D.R., 2013, Accounting restatements: a review of the literature, Working paper (The American Accounting Association): http://www2.aahq.org/AM2014/abstract.cfm?submissionID=2230

Srinavasan, S., A.S. Wahid, and G. Yu, 2015, Admitting mistakes: home country effect on the reliability of restatement reporting, The Accounting Review 90, 1201-1240.

Sue, S.H., C.L. Chin, and A.L. Chan, 2013, Exploring the causes of accounting restatements by family firms, Journal of Business Finance and Accounting 40, 1068-1094.

Wallace, W., 2000, The value relevance of accounting: the rest of the story, European Management Journal 18, 675-682. 
Wang, V., and M. Wu, 2011, The quality of financial reporting in China: An examination from an accounting restatement perspective, China Journal of Accounting Research 4, 167-196.

Xu, Y., A.L. Jiang, N. Fargher and E. Carson, 2011, Audit reports in Australia during the global financial crisis, Australian Accounting Review 21, 22-31. 
TABLE 1 - Descriptive Statistics of Misstatement Firms

\begin{tabular}{|c|c|c|c|c|c|c|}
\hline \multicolumn{7}{|c|}{ Panel A - Frequency of Misstatements b } \\
\hline & \multicolumn{4}{|c|}{ Error Years } \\
\hline & & & \multicolumn{2}{|c|}{ All } & \multicolumn{2}{|c|}{ Earliest } \\
\hline Year & $\mathrm{N}$ & $\begin{array}{l}\text { Listed } \\
\text { firms \% }\end{array}$ & $\mathrm{N}$ & $\begin{array}{l}\text { Listed } \\
\text { firms \% }\end{array}$ & $\mathrm{N}$ & $\begin{array}{l}\text { Listed } \\
\text { firms \% }\end{array}$ \\
\hline 2006 & 63 & 3.8 & 94 & 5.5 & 94 & 5.5 \\
\hline 2007 & 95 & 5.3 & 111 & 6.1 & 103 & 5.7 \\
\hline 2008 & 110 & 5.6 & 116 & 6.0 & 100 & 5.2 \\
\hline 2009 & 122 & 6.3 & 86 & 4.5 & 82 & 4.4 \\
\hline 2010 & 99 & 5.1 & 75 & 3.8 & 70 & 3.7 \\
\hline 2011 & 79 & 4.0 & 64 & 3.5 & 61 & 3.3 \\
\hline 2012 & 71 & 3.7 & 52 & 2.8 & 46 & 2.4 \\
\hline 2013 & 65 & 3.4 & 9 & 0.5 & 9 & 0.5 \\
\hline \multicolumn{7}{|l|}{ Totals: } \\
\hline 2006-2011 & 568 & 4.3 & 546 & 4.9 & 510 & 4.6 \\
\hline $2006-2013$ & 704 & 4.1 & 607 & 4.1 & 565 & 3.8 \\
\hline
\end{tabular}

Panel B - Percentage of Misstating Firms by Industry

\begin{tabular}{lcc} 
Industry Name & Misstating firms \% & Listed firms \% \\
\hline Automobiles \& Parts & 0.9 & 0.5 \\
Banks & 0.4 & 0.6 \\
Basic Resources & 26.3 & 38.1 \\
Chemicals & 1.0 & 0.9 \\
Construction \& Materials & 2.8 & 2.5 \\
Financial Services & 8.4 & 9.0 \\
Food \& Beverage & 3.8 & 2.8 \\
Health Care & 6.0 & 6.5 \\
Industrial Goods \& Services & 12.8 & 8.6 \\
Insurance & 0.1 & 0.4 \\
Media & 2.0 & 2.0 \\
Oil \& Gas & 8.5 & 8.1 \\
Personal \& Household Goods & 1.6 & 1.8 \\
Real Estate & 6.4 & 5.2 \\
Retail & 4.5 & 2.6 \\
Technology & 7.2 & 4.3 \\
Telecommunications & 2.4 & 1.3 \\
Travel \& Leisure & 2.7 & 2.1 \\
Utilities & 1.4 & 1.6 \\
Unclassified & 0.7 & 1.0 \\
\hline Total & 100.0 & 100.0
\end{tabular}

In Panel A, error years are understated more in recent sample years due to the misstatement lag - see Table 2, Panel C. Some firms disclose more than one error year in a misstatement year, causing the totals for Error Years All to be larger than the totals for Error Years Earliest. Ten earliest Error Years occur before the ASX listing and these cases are excluded from the Error Years data on the right side of Panel A. Datastream industry classifications are used in Panel B. 
TABLE 2 - Accounting Issues, Location of Initial Disclosure and Descriptive Statistics of Misstatements

\begin{tabular}{lcc}
\hline Panel A - Accounting issues & $\mathrm{N}$ & $\%$ \\
REV & 92 & 13.1 \\
EXPACCRESEST & 84 & 11.9 \\
EXPSTOCK & 41 & 5.8 \\
EXPCOS & 50 & 7.1 \\
EXPCAPDEPAM & 54 & 7.7 \\
EXPPENCONLEA & 13 & 1.8 \\
TAX & 108 & 15.3 \\
INVESTING & 71 & 10.1 \\
FINANCING & 38 & 5.4 \\
CFMISS & 15 & 2.1 \\
ISMISSEPS & 35 & 5.0 \\
DEQMISS & 50 & 7.1 \\
FNOTEDIR & 145 & 20.6 \\
ASSETMISS & 82 & 11.6 \\
COMPINC & 25 & 3.6 \\
SUBSID & 38 & 5.4 \\
CONSOL & 61 & 8.7 \\
REORG & 87 & 12.4 \\
UnSpecified & 11 & 1.6
\end{tabular}

Panel B - Location of initial disclosure

Half-year report

$\begin{array}{rr}216 & 30.7 \\ 1 & 0.1 \\ 11 & 1.6 \\ 1 & 0.1 \\ 338 & 48.0 \\ 1 & 0.1 \\ 56 & 8.0 \\ 1 & 0.1 \\ 79 & 11.2\end{array}$

Half-year report and Press

Half-year report and Announcement

Half-year report and Financial-year report

Financial-year report

Financial-year report and Press

Financial-year report and Announcement

Financial-year report, Press and Announcement

79

11.2

Panel C - Descriptive statistics of misstatement variables

\begin{tabular}{lcrrrrr} 
& Min & Median & Mean & Max & Std dev & N \\
\cline { 2 - 7 } MISSTATEMENTLAG & 0 & 1 & 1.2 & 7 & 0.8 & 704 \\
Error lag & 1 & 239 & 227.5 & 1,789 & 140.4 & 704 \\
NUMERRORS & 1 & 1 & 1.4 & 8 & 0.8 & 704 \\
Number years restated & 1 & 1 & 1.1 & 5 & 0.4 & 704 \\
Number accounting issues & 1 & 1 & 1.6 & 10 & 0.9 & 704 \\
Earnings or equity change & 0 & 1 & 0.6 & 1 & 0.5 & 704 \\
Earnings change (\%) & $-4,719.8$ & -4.9 & -39.2 & 670.8 & 292.6 & 347 \\
Equity change (\%) & -469.3 & -1.3 & -8.3 & 119.2 & 43.4 & 362 \\
\hline
\end{tabular}

In Panels A and B, \% is the percentage of all misstatements. Percentages in Panel A do not total 100 because firms can have more than one accounting issue per misstatement. Percentages in Panel B do not total 100 due to rounding. Variable descriptions for Panel A are shown in Appendix 2. MISSTATEMENTLAG is the number of years from the misstatement year to the earliest year when an error was made. Error lag is the number of days from the lodgement date of the most recent previous incorrect audited financial report to the earliest date of the misstatement. NUMERRORS is the number of accounting errors identified in a misstatement. Number years restated is the number of financial years where the impact of the error is disclosed. When no data are provided, we set the value to one year. Number accounting issues is the number of issues from Panel A of this table. Earnings or equity change equals unity if the firm's earnings or its equity decreased or increased and zero otherwise. Earnings change (\%) is the cumulative correction to earnings divided by the sum of the absolute values of prior year's reporting earnings(s). Equity change $(\%)$ is the correction to equity divided by prior-period equity. 
Table 3 - Tests of Differences in Characteristics between Misstatement Firms and Control Firms

\begin{tabular}{|c|c|c|c|c|c|c|}
\hline \multicolumn{6}{|c|}{ Panel A - Univariate Tests of Differences in Characteristics } & \multirow[b]{3}{*}{$p$-value } \\
\hline & \multicolumn{2}{|c|}{ Mean } & \multirow[b]{2}{*}{$p$-value } & \multicolumn{2}{|c|}{ Median } & \\
\hline & $\begin{array}{l}\text { Misstatement } \\
\text { Firms } \\
\end{array}$ & $\begin{array}{l}\text { Control } \\
\text { Firms }\end{array}$ & & $\begin{array}{l}\text { Misstatement } \\
\text { Firms } \\
\end{array}$ & $\begin{array}{c}\text { Control } \\
\text { Firms }\end{array}$ & \\
\hline$S I Z E$ & 17.794 & 17.362 & $<0.01$ & 17.580 & 17.072 & $<0.01$ \\
\hline$L E V$ & 0.464 & 0.407 & 0.01 & 0.388 & 0.240 & $<0.01$ \\
\hline$R O A$ & -0.192 & -0.323 & $<0.01$ & -0.014 & -0.054 & $<0.01$ \\
\hline LOSS & 0.533 & 0.603 & $<0.01$ & 1 & 1 & \\
\hline BIG4 & 0.410 & 0.458 & 0.04 & 0 & 0 & \\
\hline UNOP & 0.233 & 0.208 & 0.15 & 0 & 0 & \\
\hline$A G E$ & 2.040 & 2.074 & 0.47 & 2.073 & 2.067 & 0.66 \\
\hline$L A F$ & 11.616 & 11.196 & $<0.01$ & 11.482 & 11.035 & $<0.01$ \\
\hline$O F F$ & 3.277 & 3.400 & $<0.01$ & 3.526 & 3.689 & $<0.01$ \\
\hline$N E W$ & 0.125 & 0.105 & 0.11 & 0 & 0 & \\
\hline MINE & 0.265 & 0.375 & $<0.01$ & 0 & 0 & \\
\hline TECH & 0.106 & 0.055 & $<0.01$ & 0 & 0 & \\
\hline IFRS & 0.386 & 0.317 & $<0.01$ & 0 & 0 & \\
\hline $\mathrm{N}$ & 510 & 10,578 & & 510 & 10,578 & \\
\hline
\end{tabular}

Panel B - Results from Logistic Regression for Predicting Errors that Result in Misstatements $($ ERRORYEAR=1)

\begin{tabular}{lrrrr} 
& \multicolumn{1}{c}{ Coeff } & $p$-value & Coeff & $p$-value \\
\cline { 2 - 6 } SIZE & -0.004 & 0.947 & 0.197 & 0.016 \\
LEV & 0.148 & 0.077 & 0.063 & 0.683 \\
ROA & 0.286 & 0.001 & 0.006 & 0.959 \\
LOSS & 0.082 & 0.435 & -0.026 & 0.860 \\
BIG4 & -0.615 & 0.001 & -0.478 & 0.080 \\
UNOP & 0.291 & 0.059 & 0.315 & 0.061 \\
AGE & -0.140 & 0.088 & -0.662 & 0.001 \\
LAF & 0.304 & 0.001 & 0.140 & 0.161 \\
OFF & -0.058 & 0.001 & -0.188 & 0.080 \\
NEW & 0.211 & 0.017 & -0.072 & 0.637 \\
MINE & -0.273 & 0.047 & - & - \\
TECH & 0.518 & 0.001 & - & - \\
IFRS & 0.337 & 0.007 & 0.088 & 0.528 \\
Constant & -5.894 & 0.001 & - & - \\
Firm-fixed Effects & \multicolumn{2}{c}{ No } & \multicolumn{2}{c}{ Yes } \\
Nagelkerke R & \multicolumn{2}{c}{0.004} \\
Wald Chi sq & \multicolumn{2}{c}{0.037} & \multicolumn{2}{c}{2,313} \\
N & 119.329 & $<0.01$ & 38.511 & $<0.01$
\end{tabular}

On the left side of Panel A, two-tailed $p$-values from $t$-tests for continuous variables and from $Z$-tests for categorical variables are shown in the comparisons of means. On the right side of Panel A, two-tailed $p$-values for continuous variables from the WilcoxonMann-Whitney test are shown in the comparisons of distributions. Continuous variables except for SIZE and $O F F$ are winsorized at the $1^{\text {st }}$ and $99^{\text {th }}$ percentiles. Panel B presents logistic regression results for errors that are subsequently corrected. The two-tailed $p$-values are shown. Coefficients and $p$-values less than 0.001 are shown as 0.001 . Regressions are estimated with robust standard errors clustered by firm and year as per Gow et al. (2010). See Appendix 3 for the definitions of the independent variables and for studies justifying the expected signs for the coefficients. 
TABLE 4 - Abnormal Returns around Misstatement Announcements for All Firms and for Various Misstatement Partitions

\begin{tabular}{|c|c|c|c|c|c|c|c|c|c|}
\hline & \multirow[b]{3}{*}{$\mathrm{N}$} & \multicolumn{4}{|c|}{ METHOD 1} & \multicolumn{4}{|c|}{ METHOD 2} \\
\hline & & \multicolumn{2}{|c|}{ BETA ADJ. } & \multicolumn{2}{|c|}{ MARKET ADJ. } & \multicolumn{2}{|c|}{ BETA ADJ. } & \multicolumn{2}{|c|}{ MARKET ADJ. } \\
\hline & & Mean & p-value & Mean & p-value & Mean & p-value & Mean & p-value \\
\hline Panel A - Full Sample & & & & & & & & & \\
\hline Full Sample & 594 & -0.001 & 0.744 & 0.001 & 0.839 & -0.009 & 0.152 & -0.007 & 0.227 \\
\hline \multicolumn{10}{|c|}{ Panel B - Effects on Earnings/Equity } \\
\hline Earnings or Equity Change & 362 & -0.003 & 0.608 & -0.001 & 0.798 & -0.015 & 0.068 & -0.015 & 0.080 \\
\hline No Earnings or Equity Change & 232 & 0.001 & 0.879 & 0.004 & 0.482 & 0.002 & 0.820 & 0.005 & 0.565 \\
\hline Test of CAR Difference & & -0.004 & 0.650 & -0.006 & 0.486 & -0.017 & 0.141 & -0.019 & 0.094 \\
\hline NEGEARNEQ & 231 & -0.010 & 0.123 & -0.010 & 0.130 & -0.023 & 0.032 & -0.025 & 0.024 \\
\hline POSEARNEQ & 102 & 0.011 & 0.292 & 0.015 & 0.139 & -0.009 & 0.565 & -0.001 & 0.939 \\
\hline Test of CAR Difference & & -0.021 & 0.090 & -0.025 & 0.039 & -0.015 & 0.433 & -0.024 & 0.183 \\
\hline \multicolumn{10}{|l|}{ Panel C - Accounting Issue } \\
\hline$R E V$ & 79 & -0.016 & 0.212 & -0.017 & 0.184 & -0.014 & 0.506 & -0.021 & 0.310 \\
\hline EXPACCRESEST & 64 & 0.009 & 0.463 & 0.011 & 0.399 & -0.001 & 0.938 & -0.009 & 0.612 \\
\hline EXPSTOCK & 36 & 0.010 & 0.411 & 0.014 & 0.234 & -0.005 & 0.792 & 0.008 & 0.716 \\
\hline EXPCOS & 40 & -0.008 & 0.705 & -0.019 & 0.360 & 0.012 & 0.718 & -0.008 & 0.817 \\
\hline EXPCAPDEPAM & 44 & 0.001 & 0.996 & -0.004 & 0.833 & -0.002 & 0.943 & -0.015 & 0.646 \\
\hline EXPPENCONLEA & 4 & -0.009 & 0.858 & -0.018 & 0.764 & 0.007 & 0.778 & -0.011 & 0.809 \\
\hline$T A X$ & 98 & -0.003 & 0.731 & -0.004 & 0.639 & -0.022 & 0.140 & -0.024 & 0.109 \\
\hline INVESTING & 58 & 0.006 & 0.607 & 0.009 & 0.459 & 0.005 & 0.817 & 0.007 & 0.751 \\
\hline FINANCING & 27 & -0.015 & 0.311 & -0.012 & 0.415 & -0.002 & 0.948 & -0.009 & 0.740 \\
\hline CFMISS & 13 & 0.016 & 0.422 & 0.016 & 0.392 & 0.013 & 0.677 & 0.004 & 0.900 \\
\hline ISMISSEPS & 29 & -0.005 & 0.722 & -0.005 & 0.771 & -0.029 & 0.246 & -0.032 & 0.246 \\
\hline DEQMISS & 38 & -0.025 & 0.214 & -0.022 & 0.296 & -0.010 & 0.745 & -0.001 & 0.988 \\
\hline FNOTEDIR & 115 & 0.004 & 0.555 & 0.010 & 0.129 & 0.000 & 0.973 & 0.004 & 0.649 \\
\hline ASSETMISS & 64 & 0.001 & 0.890 & 0.002 & 0.870 & 0.003 & 0.857 & 0.004 & 0.769 \\
\hline COMPINC & 22 & -0.008 & 0.692 & -0.001 & 0.969 & -0.054 & 0.110 & -0.050 & 0.152 \\
\hline$S U B S I D$ & 31 & 0.011 & 0.597 & 0.021 & 0.279 & -0.002 & 0.955 & 0.012 & 0.649 \\
\hline CONSOL & 48 & 0.001 & 0.981 & -0.001 & 0.949 & -0.016 & 0.542 & -0.018 & 0.498 \\
\hline$R E O R G$ & 76 & 0.011 & 0.279 & 0.014 & 0.166 & 0.033 & 0.036 & 0.039 & 0.009 \\
\hline UNSPECIFIED & 11 & -0.006 & 0.713 & -0.008 & 0.618 & -0.021 & 0.705 & -0.024 & 0.687 \\
\hline \multicolumn{10}{|c|}{ Panel D - Returns by Other Types of Severity } \\
\hline FRAUD & 12 & -0.058 & 0.035 & -0.054 & 0.067 & -0.068 & 0.273 & -0.087 & 0.215 \\
\hline Number of Errors $>1$ & 139 & -0.004 & 0.580 & -0.003 & 0.698 & -0.005 & 0.671 & -0.007 & 0.568 \\
\hline \multicolumn{10}{|c|}{ Panel E - Returns by Disclosure Salience } \\
\hline STEALTH & 477 & 0.002 & 0.665 & 0.004 & 0.372 & -0.005 & 0.504 & -0.003 & 0.718 \\
\hline NONSTEALTH & 117 & -0.015 & 0.039 & -0.013 & 0.087 & -0.025 & 0.028 & -0.027 & 0.023 \\
\hline Test of CAR Difference & & 0.017 & 0.048 & 0.017 & 0.054 & 0.020 & 0.126 & 0.024 & 0.075 \\
\hline
\end{tabular}


TABLE 5 - Descriptive Statistics for Variables used in Regressions of Abnormal Returns

\begin{tabular}{lcccccccrr}
\hline & MIN & P1 & P5 & P50 & P95 & P99 & MAX & MEAN & SD \\
\hline CAR_MET1_BETAADJ & -0.301 & -0.301 & -0.175 & 0.001 & 0.154 & 0.359 & 0.359 & -0.001 & 0.097 \\
CAR_MET1_MKTADJ & -0.315 & -0.315 & -0.163 & 0 & 0.157 & 0.344 & 0.344 & 0.001 & 0.096 \\
CAR_MET2_BETAADJ & -0.506 & -0.506 & -0.275 & -0.004 & 0.211 & 0.516 & 0.516 & -0.009 & 0.147 \\
CAR__MET2_MKTADJ & -0.522 & -0.522 & -0.276 & -0.003 & 0.218 & 0.507 & 0.507 & -0.007 & 0.146 \\
& & & & & & & & & \\
NEGEARNEQ & 0 & 0 & 0 & 0 & 1 & 1 & 1 & 0.389 & 0.488 \\
CONSOL_EQ_TA & -1.138 & -0.587 & -0.102 & 0 & 0.039 & 0.237 & 0.771 & -0.013 & 0.108 \\
REV & 0 & 0 & 0 & 0 & 1 & 1 & 1 & 0.133 & 0.340 \\
COREEXPENSES & 0 & 0 & 0 & 0 & 1 & 1 & 1 & 0.278 & 0.448 \\
FRAUD & 0 & 0 & 0 & 0 & 0 & 1 & 1 & 0.020 & 0.141 \\
STEALTH & 0 & 0 & 0 & 1 & 1 & 1 & 1 & 0.803 & 0.398 \\
NUMERRORS & 1 & 1 & 1 & 1 & 3 & 5 & 6 & 1.333 & 0.723 \\
SIZE & 0 & 13.559 & 14.937 & 17.648 & 21.932 & 23.250 & 26.426 & 17.952 & 2.280 \\
ROA & -10.099 & -3.864 & -1.303 & -0.025 & 0.180 & 0.316 & 0.553 & -0.244 & 0.916 \\
LEV & 0.003 & 0.006 & 0.020 & 0.391 & 0.937 & 1.903 & 8.507 & 0.448 & 0.608 \\
EARNINGS_SURPRISE & -1.800 & -1.800 & -0.560 & -0.001 & 0.433 & 4.133 & 4.133 & 0.011 & 0.571 \\
\hline This table presents extreme values, various percentiles and mean and standard deviation statistics for the dependent and independent variables
\end{tabular}
used in the abnormal return regressions in Tables 6 and 7. Variable definitions are shown in Appendices 3 and 4. 
TABLE 6 - OLS Regression Results for Cumulative Abnormal Returns around Misstatement Announcements

\begin{tabular}{|c|c|c|c|c|c|c|c|c|}
\hline & \multicolumn{4}{|c|}{ METHOD 1} & \multicolumn{4}{|c|}{ METHOD 2} \\
\hline & \multicolumn{2}{|c|}{ BETA ADJ. } & \multicolumn{2}{|c|}{ MARKET ADJ. } & \multicolumn{2}{|c|}{ BETA ADJ. } & \multicolumn{2}{|c|}{ MARKET ADJ. } \\
\hline & Coef & p-value & Coef & $\mathrm{p}$-value & Coef & $\mathrm{p}$-value & Coef & $\mathrm{p}$-value \\
\hline NEGEARNEQ & -0.011 & 0.170 & -0.013 & 0.166 & -0.027 & 0.025 & -0.028 & 0.028 \\
\hline CONSOL_EQ_TA & 0.043 & 0.342 & 0.037 & 0.384 & 0.022 & 0.818 & 0.021 & 0.801 \\
\hline$R E V$ & -0.015 & 0.030 & -0.017 & 0.001 & -0.005 & 0.687 & -0.012 & 0.184 \\
\hline COREEXPENSES & 0.007 & 0.404 & 0.002 & 0.857 & 0.011 & 0.410 & 0.003 & 0.828 \\
\hline FRAUD & -0.040 & 0.203 & -0.035 & 0.283 & -0.033 & 0.612 & -0.047 & 0.459 \\
\hline STEALTH & 0.014 & 0.026 & 0.013 & 0.045 & 0.024 & 0.077 & 0.025 & 0.040 \\
\hline NUMERRORS & 0.001 & 0.705 & 0.001 & 0.709 & 0.006 & 0.517 & 0.004 & 0.591 \\
\hline$S I Z E$ & -0.001 & 0.723 & -0.002 & 0.270 & 0.005 & 0.126 & 0.003 & 0.268 \\
\hline$R O A$ & 0.003 & 0.439 & 0.006 & 0.155 & 0.005 & 0.485 & 0.009 & 0.029 \\
\hline$L E V$ & 0.001 & 0.951 & -0.001 & 0.931 & 0.020 & 0.104 & 0.016 & 0.132 \\
\hline EARNINGS_SURPRISE & 0.006 & 0.030 & 0.006 & 0.095 & 0.007 & 0.464 & 0.010 & 0.255 \\
\hline INTERCEPT & 0.011 & 0.746 & 0.044 & 0.195 & -0.121 & 0.048 & -0.080 & 0.146 \\
\hline Industry and Year dummies & Yes & & Yes & & Yes & & Yes & \\
\hline Adj R-squared & $3.27 \%$ & & $4.06 \%$ & & $3.10 \%$ & & $3.85 \%$ & \\
\hline $\mathrm{N}$ & 594 & & 594 & & 594 & & 594 & \\
\hline
\end{tabular}




\section{TABLE 7 - OLS Regression Results for Cumulative Abnormal Returns around Misstatement}

Announcements: Interactions of Key Variables with Stealth Indicator

\begin{tabular}{|c|c|c|c|c|c|c|c|c|}
\hline & \multicolumn{4}{|c|}{ METHOD 1} & \multicolumn{4}{|c|}{ METHOD 2} \\
\hline & \multicolumn{2}{|c|}{ BETA ADJ. } & \multicolumn{2}{|c|}{ MARKET ADJ. } & \multicolumn{2}{|c|}{ BETA ADJ. } & \multicolumn{2}{|c|}{ MARKET ADJ. } \\
\hline & Coef & p-value & Coef & p-value & Coef & $\mathrm{p}$-value & Coef & p-value \\
\hline NEGEARNEQ & -0.028 & 0.058 & -0.034 & 0.051 & -0.064 & 0.001 & -0.063 & 0.003 \\
\hline NEGEARNEQ_INT & 0.021 & 0.191 & 0.025 & 0.119 & 0.043 & 0.003 & 0.042 & 0.018 \\
\hline CONSOL_EQ_TA & 0.023 & 0.425 & 0.011 & 0.699 & 0.020 & 0.512 & -0.004 & 0.943 \\
\hline CONSOL_EQ_TA_INT & 0.033 & 0.371 & 0.040 & 0.320 & 0.015 & 0.886 & 0.041 & 0.737 \\
\hline$R E V$ & -0.001 & 0.963 & -0.008 & 0.737 & -0.019 & 0.711 & -0.032 & 0.450 \\
\hline$R E V \_I N T$ & -0.017 & 0.463 & -0.011 & 0.591 & 0.022 & 0.659 & 0.029 & 0.502 \\
\hline COREEXPENSES & 0.018 & 0.100 & 0.008 & 0.514 & 0.063 & 0.000 & 0.028 & 0.099 \\
\hline COREEXPENSES_INT & -0.012 & 0.495 & -0.006 & 0.733 & -0.061 & 0.002 & -0.028 & 0.211 \\
\hline FRAUD & -0.037 & 0.276 & -0.030 & 0.408 & -0.030 & 0.645 & -0.037 & 0.561 \\
\hline STEALTH & 0.013 & 0.070 & 0.008 & 0.275 & 0.019 & 0.250 & 0.014 & 0.307 \\
\hline NUMERRORS & 0.001 & 0.722 & 0.001 & 0.749 & 0.005 & 0.543 & 0.003 & 0.662 \\
\hline SIZE & -0.001 & 0.793 & -0.002 & 0.352 & 0.005 & 0.120 & 0.004 & 0.233 \\
\hline$R O A$ & 0.002 & 0.602 & 0.006 & 0.230 & 0.004 & 0.651 & 0.007 & 0.141 \\
\hline$L E V$ & 0.001 & 0.963 & -0.001 & 0.929 & 0.020 & 0.129 & 0.016 & 0.146 \\
\hline EARNINGS_SURPRISE & 0.006 & 0.048 & 0.006 & 0.126 & 0.008 & 0.409 & 0.010 & 0.258 \\
\hline INTERCEPT & 0.009 & 0.800 & 0.043 & 0.227 & -0.120 & 0.037 & -0.078 & 0.131 \\
\hline Industry and Year dummies & Yes & & Yes & & Yes & & $\mathrm{Ye}$ & \\
\hline R-squared & $3.43 \%$ & & $4.25 \%$ & & $3.64 \%$ & & $4.24^{\circ}$ & \\
\hline $\mathrm{N}$ & 594 & & 594 & & 594 & & 59 & \\
\hline
\end{tabular}


TABLE 8 - Results from Logistic Regressions for Predicting Announcement of Misstatement News on the Same Date as Earnings (NEWS_SAME_EARN=1), with and without STEALTH interactions

NEGNI_EFFECT_BIG
NEGNI_EFFECT_BIG $\times$ STEALTH
NEGNI_EFFECT_SMALL
NEGNI_EFFECT_SMALL $\times$ STEALTH
POSNI_EFFECT
POSNI_EFFECT $\times$ STEALTH
REV
REV $\times$ STEALTH
COREEXPENSES
COREEXPENSES $\times$ STEALTH
FRAUD
NUMERRORS
MISSTATEMENTLAG
STEALTH
SIZE
LEV
ROA
BIG4
AGE
Constant

No interactions

Including stealth

interactions

\begin{tabular}{clrr} 
Coeff & $p$-value & Coeff & $p$-value \\
\hline 1.437 & 0.001 & 0.950 & 0.139 \\
& & 1.734 & 0.152 \\
0.354 & 0.329 & 0.701 & 0.331 \\
& & -0.479 & 0.559 \\
0.581 & 0.105 & 1.220 & 0.090 \\
& & -0.849 & 0.292 \\
1.035 & 0.014 & 1.143 & 0.036 \\
& & -0.378 & 0.648 \\
0.762 & 0.019 & 0.749 & 0.172 \\
& & 0.056 & 0.935 \\
-2.403 & 0.001 & -1.352 & 0.039 \\
-0.016 & 0.904 & 0.062 & 0.721 \\
0.311 & 0.010 & 0.168 & 0.155 \\
3.511 & 0.001 & 3.570 & 0.001 \\
0.111 & 0.088 & 0.112 & 0.092 \\
0.084 & 0.646 & 0.045 & 0.812 \\
-0.150 & 0.333 & -0.187 & 0.236 \\
0.120 & 0.664 & 0.121 & 0.662 \\
-0.280 & 0.046 & -0.298 & 0.035 \\
-3.771 & 0.002 & -3.771 & 0.003 \\
\multicolumn{4}{c}{0.509} \\
0.502 & \multicolumn{3}{c}{164.591} \\
171.278 & \multicolumn{3}{c}{703} \\
703
\end{tabular}

Nagelkerke $\mathrm{R}^{2}$

Wald Chi sq

$\mathrm{N}$

171.278

164.59

Logistic regression results for predicting misstatement news released on the earnings announcement date. The twotailed $p$-values are shown. Coefficients and $p$-values less than 0.001 are shown as 0.001 . Regressions are estimated with robust standard errors clustered by firm and year as in Gow et al. (2010). Variable definitions are shown in Appendices 3 and 4 . 